UNIVERSIDADE DE SÃO PAULO

FACULDADE DE MEDICINA DE RIBEIRÃO PRETO

PÓS GRADUAÇÃO EM SAÚDE DA CRIANÇA E DO ADOLESCENTE

ADRIANA CARNEVALE DA SILVA

Infecção congênita por CMV: potenciais marcadores preditivos de alterações tardias em crianças assintomáticas

Ribeirão Preto- SP 
Infecção congênita por CMV: potenciais marcadores preditivos de alterações tardias em crianças assintomáticas

Dissertação de Mestrado apresentada ao Departamento de Pós Graduação da Faculdade de Medicina de Ribeirão Preto da Universidade de São Paulo, para obtenção do título de Mestre na área de Pediatria.

Orientadora: Dra Aparecida Yulie Yamamoto

Ribeirão Preto- SP 
AUTORIZO A REPRODUÇÃO E DIVULGAÇÃO TOTAL OU PARCIAL DESTE

TRABALHO, POR QUALQUER MEIO CONVENCIONAL OU ELETRÔNICO, PARA FINS DE ESTUDO E PESQUISA, DESDE QUE CITADA A FONTE.

FICHA CATALOGRÁFICA

\section{Carnevale-Silva, Adriana.}

Infecção congênita por CMV: potenciais marcadores preditivos de alterações tardias em crianças assintomáticas. Ribeirão Preto, 2017.

77 p. : il. ; $30 \mathrm{~cm}$.

Dissertação de Mestrado apresentada à Faculdade de Medicina de Ribeirão Preto - Universidade de São Paulo. Área de concentração: Pediatria.

Orientadora: Yamamoto, Aparecida Yulie

1. Citomegalovírus, 2. Infecções congênitas,

3. Neurossonografia transfontanelar, 4. Surdez neurossensorial 
CARNEVALE-SILVA, A.

Infecção congênita por CMV: potenciais marcadores preditivos de alterações tardias em crianças assintomáticas.

Dissertação de Mestrado apresentada à Faculdade de Medicina de Ribeirão Preto, Universidade de São Paulo para obtenção do titulo de Mestre.

Aprovado em:

Banca Examinadora

Prof(a). Dr(a).: Instituição:

Julgamento: Assinatura:

Prof(a). Dr(a).: Instituição:

Julgamento: Assinatura:

Prof(a). Dr(a).: Instituição:

Julgamento: Assinatura: 


\section{AGRADECIMENTOS}

A Deus, por me conceder saúde, equilíbrio e capacidade para entender que tudo nesta vida é um verdadeiro aprendizado.

Aos meus pais, Stella Maris e José Reinaldo, pelo amor e dedicação incondicionais, incentivo em todos os momentos e pelos bons exemplos que me tornaram quem sou hoje. Minha eterna gratidão.

À minha irmã Juliana que, além de irmã, é uma verdadeira amiga e sempre esteve ao meu lado, me ajudando, impulsionando e aconselhando. Obrigada pela parceria e amor.

À minha orientadora Doutora Aparecida Yulie Yamamoto, pessoa por quem tenho profunda admiração e respeito, pelo exemplo de pessoa e profissional que é e pelo privilégio de poder conviver e aprender. Agradeço a confiança e a amizade criada nesses anos de trabalho.

À estimada professora Doutora Marisa Márcia Mussi pelo apoio na vida profissional e acadêmica.

À equipe da Divisão de Radiologia do Departamento de Clínica Médica do Hospital das Clínicas da FMRP-USP, especialmente à Dra Sara Teixeira e Prof. Dr Jorge Elias Junior.

À equipe do setor de Fonoaudiologia do Departamento de Otorrinolaringologia do Hospital das Clínicas da FMRP-USP, especialmente às fonoaudiólogas Alessandra Kerli Manfredi, Juliana Cavalcante, Prof. Dra Adriana Ribeiro Tavares Anastácio, Ana Cláudia Mirandola.

À equipe do IRAP (Ambulatório de Reabilitação Auditiva Precoce), especialmente ao Prof. Dr Eduardo Massuda Tanaka e Prof. Dra Myriam Lima Isaac.

À toda equipe envolvida na pesquisa, especialmente às colaboradoras de pesquisa: Tabata Garcia Fernandes, Maria Beatriz Cruz de Souza, Maria Natalina Ferreira da Silva, Eunice Gonçalves da Silva, Alessandra Santos Zampolo e também à Assistente Social Adriana Morimoto, que tiveram participação fundamental no desenvolvimento do estudo.

Às Pediatras da equipe do ICOP (Ambulatório de Infecções Congênitas e Perinatais do Hospital das Clínicas da FMRP-USP), Fernanda Tomé e Lillian Espinheira. 
Ao nosso querido bioestatístico Davi Casale Aragon pela atenção e paciência em todos os momentos, e pelo importante trabalho realizado.

A todos meus amigos, em especial aos que apareceram durante essa trajetória e me auxiliaram de algum modo nos momentos difíceis.

O meu profundo respeito e agradecimento às famílias envolvidas no estudo em prol do avanço no conhecimento.

Aos integrantes da banca examinadora, pelo tempo despendido com a minha dissertação. 
"Existe um caminho através de cada obstáculo."

(Yogi Bhajan) 


\title{
RESUMO
}

\author{
CARNEVALE-SILVA, A. Infecção congênita por CMV: potenciais marcadores \\ preditivos de alterações tardias em crianças assintomáticas. 2017. 77f. Dissertação \\ (Mestrado). Faculdade de Medicina de Ribeirão Preto - Universidade de São Paulo, Ribeirão \\ Preto, 2017.
}

Os objetivos do estudo consistiram em verificar o impacto da infecção congênita por CMV ao nascer e avaliar potenciais preditores prognósticos de anormalidades tardias em uma coorte de criança s com esta infecção. Métodos: Por meio de uma triagem neonatal, 66 de 11.957 crianças foram identificadas como portadoras de infecção congênita por CMV. Todas as crianças infectadas sintomáticas e assintomáticas foram avaliadas ao nascimento por meio de exame físico detalhado, avaliação auditiva, fundoscopia ocular, neurossonografia transfontanelar (NTF) realizada por neurorradiologista infantil e quando alterada, foram submetidas à ressonância magnética de encéfalo (RMc). Análise de regressão logística foi realizada para verificar a associação de potenciais fatores de risco para ocorrência de surdez neurossensorial relacionada ao CMV e/ou presença de achados anormais em NTF e/ou RMc. A análise da Curva ROC foi utilizada para avaliar a associação da carga do DNA do CMV expresso em $\log 10$, com a presença de sintomas ao nascer, achados anormais em NTF e/ou RMc e ocorrência de surdez neurosensorial. Resultados: Em 66 crianças infectadas, os sinais clínicos sugestivos de infecção congênita ao nascer foram observados em 8/66 (12,12\%; IC95\%: 5,74-23,03), sendo considerados sintomáticos. As 58 crianças restantes foram considerados assintomáticos. A surdez neurossensorial foi observada em 8/66 (12,12\%; IC95\%: 5,74-23,03\%) das crianças. Destas, 4/58 (6,9\%; IC95\%: 2,23- 17,54\%) e 4/8 (50\%; IC95\%: 17,44-82,55\%) crianças eram assintomáticas e sintomáticas, respectivamente. Achados de NTF e/ou RMc sugestivas de infecção congênita foram observadas em 7 de 8 crianças sintomáticas (87,5\%; IC95\%: 46,67-99,34\%). Dentre as 58 assintomáticas, $53(92,4 \%)$ completaram todas as avaliações e destas $29 / 52$ apresentaram alterações sugestivas de infecção congênita em NTF e/ou RMc (55,7\%; IC95\%: 41,41 - 69,27\%). O achado mais comum foi a vasculopatia lenticuloestriada acompanhado ou não de cistos subpendimários (13/29: 43.3\%). Outros achados anormais foram os cistos subpendimários como achado isolado (11/29: 37.9\%), calcificação única ou periventricular com ou sem áreas de gliose (4/29: 13,8\%) e ventriculomegalia (4/29: 13,8\%). Análise de regressão logística mostrou que apenas a presença de sintomas clínicos ao nascer foi preditivo para a ocorrência de surdez neurossensorial. Achados de neuroimagens (NTF e/ou RMc) foram observados em 3 de 4 crianças assintomáticas (75\%) enquanto $26(54,2 \%)$ de 48 crianças sem surdez tinham avaliações normais de NTF e/ou RMc ( $p=0,42$; RR:2,38: IC95\%: 0,26-21,39). Nenhum dos outros fatores de risco foram independentemente associados com surdez. A presença de plaquetopenia e/ou níveis altos de gama glutamil transferase (rGT) foi associado com a presença de achados anormais em NTF e/ou RMc uma análise univariada. O poder discriminatório pela determinação do ponto de corte do valor da carga do DNA do CMV foi avaliada pela área abaixo da curva ROC (AUC) e não houve associação entre a carga viral e a ocorrência de surdez e/ou achados anormais de NTF e/ou RMc. Conclusões: Embora a triagem neonatal da infecção congênita por CMV permita identificar a maioria das crianças infectadas que são clinicamente assintomáticas ao nascer, uma proporção significante destas crianças poderá ser beneficiada por uma avaliação do sistema nervoso central através de NTF, uma vez que, achados anormais são muito frequentes. Embora não tenha sido possível determinar fatores independentemente preditivos de ocorrência de surdez neurossensorial, os achados de NTF podem ser potenciais fatores preditivos de anormalidades tardias em crianças assintomáticas.

Palavras-chave: Citomegalovírus; Infecção congênita; Neurossonografia transfontanelar; Surdez Neurossensorial. 


\begin{abstract}
CARNEVALE-SILVA, A. Congenital CMV infection: potential prognostic predictors of late abnormalities in asymptomatic infants. 2017. 77f. Dissertação (Mestrado). Faculdade de Medicina de Ribeirão Preto - Universidade de São Paulo, Ribeirão Preto, 2017.

The objectives of this study were to verify the impact of congenital cytomegalovirus (CMV) infection at birth and to evaluate potential prognostic predictors of late abnormalities in a cohort of children with this infection. Methods: By means of a CMV neonatal screening, 66 of 11.957 infants were identified as congenitally infected. Infants with and without clinical abnormalities detectable at birth underwent physical examination, cranial ultrasound performed by a paediatric radiologist and/or cranial magnetic resonance imaging, ocular fundoscopy, and hearing evaluation using evoked otoacoustic emissions and auditory brainstem response. Logistic regression analysis was carried out to verify the association between the risk factors for occurrence of hearing loss related to CMV and/ or abnormal cranial ultrasound findings. ROC curve was plotted using the $\log 10$ value of CMV DNA load to evaluate the association between viral load and clinical symptoms at birth, abnormal cranial ultrasound findings and hearing loss. Results: Of all 66 infected children, the clinical signs suggestive of congenital infection at birth were observed in 8/66 (12.12\%; IC95\%: 5.7423.03) symptomatic infants. Sensorineural hearing loss was observed in $8 / 66(12,12 \%$; IC95\%: 5.74-23.03\%) children. Of these, 4/58 (6,9\%; IC95\%: 2.23-17.54\%) and 4/8 (50\%; IC95\%: 17,44-82.55\%) children were asymptomatic and symptomatic, respectively. Cranial ultrasound findings suggestive of congenital infection were observed in 7 of the 8 symptomatic children (87.5\%; IC95\%: 46.67-99.34\%). Among the 58 asymptomatic infants, 53 underwent complete evaluation and $29 / 52$ had abnormal cranial ultrasound results $(55,7 \%$; IC95\%: 41.41 - 69,27\%). The most prevalent findings was lenticulostriate vasculopathy with subependymal pseudocysts present in 13 of the $/ 29$ (43.3\%) infants with cranial ultrasound. Other abnormal findings were isolated subependymal pseudocysts (11/29: 37.9\%); single or periventricular calcifications and/or gliosis (4/29: 13.8\%); and ventriculomegaly (4/29: $13,8 \%$ ). Logistic regression analysis showed that only the presence of clinical findings predicted the occurrence of hearing loss. Cranial ultrasound findings were observed in 3 of asymptomatic infants $(75.0 \%)$ while $26(54.2 \%)$ of 48 infants with no hearing loss had abnormal imaging features ( $p=0,42$; RR:2,38: IC95\%: 0,26-21,39). None of the other factors risk were independely associated with development of hearing loss. The presence of thrombocytopenia and/or high level of gamma-glutamyltranspeptidase (rGT) was associated with cranial ultrasound findings on univariated analysis. No discrimination power was achieved using the area under the ROC curve to verify the association between CMV DNA load in the urine of the infected children and the developing of hearing loss, presence of cranial ultrasound findings and clinical signs at birth. Conclusions: Although a neonatal screening of cCMV will identify the majority of infected infants who are clinically asymptomatic, a significant proportion of them could benefit from a central nervous system image evaluation, since abnormal findings are frequent. Althoug it was not possible to determine risk factors that are independently associated to development of sensorineural hearing loss, cranial ultrasound findings could be a potential prognostic markers of adverse outcomes of congenital CMV in asymptomatic infants.
\end{abstract}

Keywords: Cytomegalovirus; Congenital infection; Cranial ultrasound; Sensorineural hearing loss. 


\section{LISTA DE ABREVIATURAS}

CMV - Citomegalovírus

HCFMRP- USP - Hospital das Clínicas da Faculdade de Medicina de Ribeirão Preto da Universidade de São Paulo

CRSM-Mater - Centro de Referência da Saúde da Mulher- Mater

US - Ultrassonografia

TC- Tomografia Computadorizada

NTF - Neurossonografia transfontanelar

RMc - Ressonância magnética cerebral

SNC - Sistema Nervoso Central

VLE - Vasculopatia lenticuloestriada

RN - Recém Nascido

PCR - Reação em Cadeia de Polimerase 


\section{LISTA DE FIGURAS}

Figura 1: Proporção de crianças infectadas congenitamente pelo CMV com presença e ausência de achados clínicos ao nascer

Figura 2: Neurossonografia transfontanelar com imagem de calcificação periventricular puntiforme

Figura 3: Neurossonografia transfontanelar mostrando cistos subependimários bilaterais .... 40

Figura 4: Ressonância magnética cerebral mostrando ventriculomegalia supratentorial e cistos subependimários

Figura 5: Curva ROC obtida para as variáveis carga viral e ocorrência de surdez com os indicadores de sensibilidade e especificidade

Figura 6: Curva ROC obtida para a carga viral e achados anormais em NTF e/ou RMc com os indicadores de sensibilidade e especificidade.

Figura 7: Curva ROC obtida para a carga viral e presença de sinais clínicos sugestivos de infecção congênita com os indicadores de sensibilidade e especificidade. 


\section{LISTA DE TABELAS}

Tabela 1: Protocolo de monitoramento audiológico de crianças selecionadas para seguimento

Tabela 2: Características dos RN triados para a detecção da infecção congênita pelo CMV no HC-FMRP e CRSM-Mater, no período de outubro de 2013 a agosto de 2016, e daqueles detectados como infectados congenitamente pelo vírus

Tabela 3: Principais achados clínicos ao nascer observados em crianças sintomáticas com infecção congênita por CMV

Tabela 4: Principais achados na NTF sugestivos de infecção congênita por CMV observados em crianças consideradas assintomáticas ao nascer

Tabela 5: Estimativa do risco relativo (RR) e seu intervalos de confiança para verificar associação entre presença de alteração de exames laboratoriais, alteração de neuroimagens (NTF e/ou RMc) e sinais clínicos com a ocorrência de surdez neurossensorial

Tabela 6: Razão de risco (RR) e seus intervalos de confiança $(95 \%$ IC) para testar associação entre alterações de exames laboratoriais e alterações de neuroimagens (NTF e/ou RMc)

Tabela 7: Estimativa do risco relativo e seus intervalos de confiança para verificar associação entre alterações de exames laboratoriais e alterações de neuroimagens (NTF e/ou RMc)

Tabela 8: Estimativa do risco relativo e seus intervalos de confiança para determinar a associação entre alterações de exames laboratoriais e ocorrência de surdez neurosensorial (análise univariada).

Tabela 9: Risco relativo e seu intervalo de confiança para associação entre a presença de alterações de neuroimagens (NTF e/ou RMc) e ocorrência de surdez neurossensorial 


\section{SUMÁRIO}

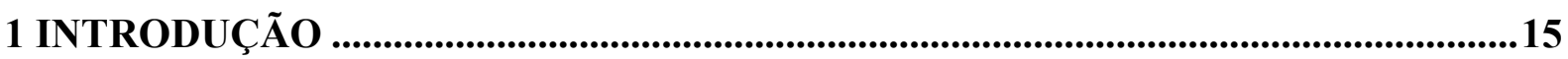

1.1 Justificativas para a realização do estudo ..................................................................... 18

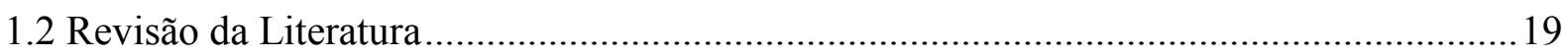

1.2.1 Principais repercussões clínicas da infecção congênita por CMV .................................19

1.2.2 Anormalidades das estruturas cerebrais e alterações em neuroimagens secundárias à

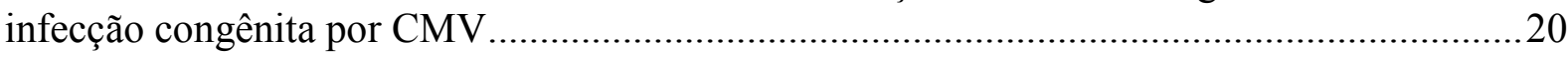

1.2.3 Insuficiência placentária: dano vascular, hipóxia e permeabilidade alterada.................21

1.2.4 Alterações oculares da infecção congênita por CMV .................................................22

1.2.5 Uso dos antivirais para tratamento da infecção congênita pelo CMV ...........................23

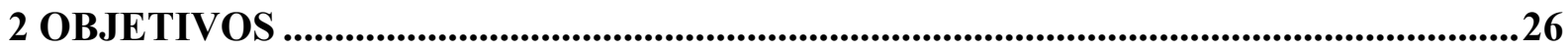

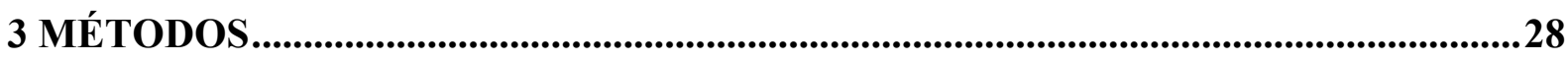

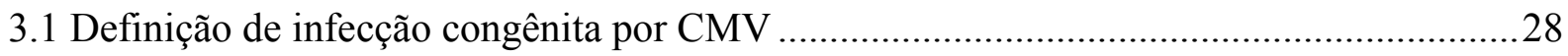

3.2 Avaliação das crianças com infecção congênita confirmada por CMV .............................29

3.3 Avaliação audiológica das crianças infectadas por CMV ................................................30

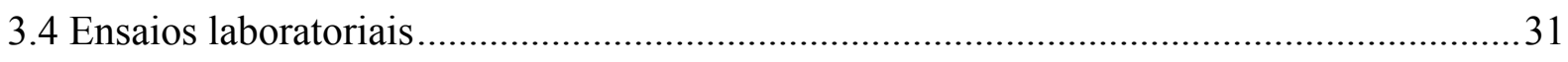

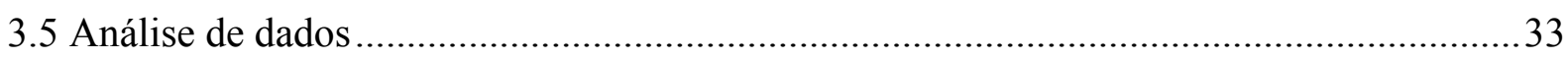

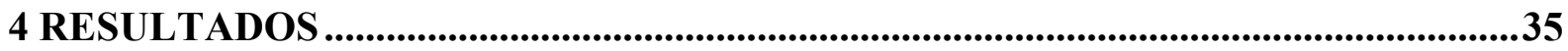

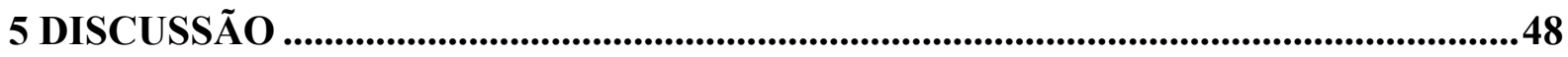

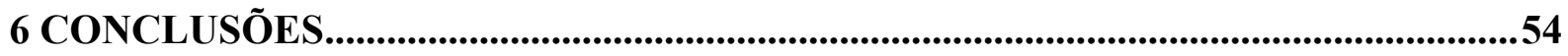

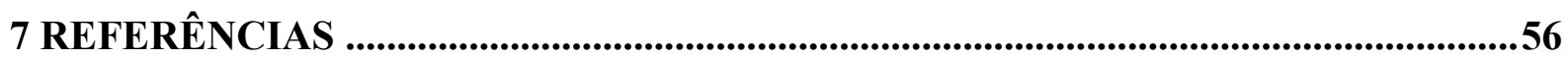

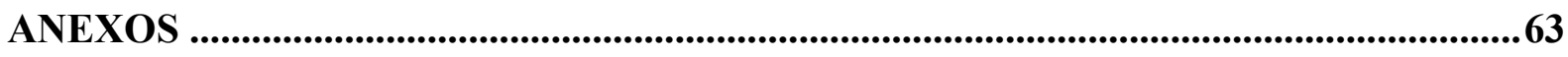

Anexo 1 - Ofícios do Comitê de Ética de autorização da pesquisa no HCFMRP....................63

Anexo 2 - Formulários com os Registros dos pacientes da pesquisa .....................................64

Anexo 3 - Cálculos da sensibilidade e especificidade para cada valor da carga do DNA do CMV e sua associação com a ocorrência de surdez, alterações de NTF e/ou RMc e sinais clínicos sugestivos de infecção congênita por CMV. 
Anexo 4 - Achados de NTF em 29 crianças e respectivos achados de TC e/ou RMc.

Anexo 5 - Achados de neuroimagens e exames laboratoriais, respectivas cargas virais, presença ou ausência de restrição do crescimento intrauterino e ocorrência de surdez em 66 crianças com infecção congênita por CMV ....................................................................... 76 
1 Introdução 


\section{INTRODUÇÃO}

Citomegalovírus humano (CMV) são vírus da família Herpesviridae, subfamília Betaherpesvirinae e gênero citomegalovirus. O CMV é reconhecido como o maior membro desta família, com diâmetro de aproximadamente $200 \mathrm{~nm}$, constituído por um envelope glicoproteico, tegumento e capsídio com simetria icosaédrica. O genoma é constituído por ácido desoxirribonucleico (DNA) de fita dupla contendo cerca de 230.000 pares de bases $(1,2,3)$.

O único reservatório do CMV é o próprio homem, que o transmite por meio de contato próximo com fluidos corporais tais como a saliva, sangue, urina, secreções cervicais, esperma, colostro e leite materno (2). Desta forma, as infecções por estes vírus são muito frequentes, e ocorrem em todo o mundo, mais comumente em populações de nível socioeconômico mais baixo $(4,5,6)$.

A infecção primária pode ocorrer no período pré-natal (infecção congênita), perinatal ou pós-natal. Em indivíduos imunocompetentes, geralmente, a infecção é assintomática mas, a exemplo de outros herpesvírus, o CMV pode permanecer latente no interior de vários órgãos e tecidos com períodos de reativação. As células mononucleares do sangue periférico parecem ser os maiores sítios de latência do CMV (7). Após a infecção primária, o vírus pode manter a replicação no hospedeiro infectado, durante meses a anos, caracterizando as infecções persistentes (8).

As infecções recorrentes ou não primárias por CMV podem ser secundárias à reativação do vírus ou à reinfecção por cepas virais diferentes $(8,9)$. Em contraste com a maioria das infecções virais congênitas, a infecção congênita por CMV pode ocorrer em recém nascidos filhos de mulheres com imunidade pré-concepcional, sendo a causa mais comum de infecções virais intrauterinas e perinatais em todo o mundo $(10,11,12)$.

A prevalência desta infecção ao nascer varia em diferentes populações de 0,2 a 2,2\% $(4,13,14)$. Altas taxas de infecção congênita por CMV tem sido relatadas em populações com alta soroprevalência materna como no Brasil (15). No Brasil, na cidade de Ribeirão Preto, a prevalência da infecção congênita por CMV é de 1\% em uma população com soroprevalência materna de 97\% (16,17). Uma triagem neonatal sistemática para infecção congênita por CMV foi realizada nesta região, durante um período de 4 anos, incluindo $85,3 \%$ de todos os nascidos vivos ou $44 \%$ dos nascimentos nessa região de São Paulo. O estudo foi realizado em dois hospitais públicos (Hospital das Clinicas da Faculdade de Medicina de Ribeirão Preto, Universidade de São Paulo, Brasil - HCFMRP e Centro de Referência em Saúde da Mulher 
(CRSM - Mater). Do total de 8047 triados, 87 eram infectados com o CMV (1,08\%). A taxa de infecção congênita por CMV foi semelhante aos relatados em estudos norte-americanos e europeus $(18,19,20)$.

Diferentes estudos epidemiológicos realizados em países desenvolvidos têm mostrado que aproximadamente $10 \%$ das crianças infectadas congenitamente apresentam manifestações clínicas da doença ao nascer, enquanto a grande maioria (90\%) são clinicamente assintomáticas $(4,14)$. Ainda, estes estudos têm mostrado que dentre as sintomáticas, 70 a $90 \%$ poderão evoluir com sequelas neurológicas graves e permanentes resultando em comprometimento importante do desenvolvimento neuropsicomotor e cerca de 50 a $60 \%$ destas crianças terão perda auditiva neurossensorial unilateral ou bilateral de alta gravidade $(19,20)$. No Brasil, na cidade de Ribeirão Preto, a infecção congênita sintomática ocorreu em $8,1 \%$ das crianças, sendo os achados mais frequentemente encontrados a icterícia colestática, petéquias, plaquetopenia, hepatoesplenomegalia e calcificações cerebrais (17).

Dentre as assintomáticas, $5 \%$ a $15 \%$ poderão desenvolver anormalidades tardias que variam de danos estruturais ao sistema nervoso central a distúrbios do sistema sensorial, especialmente da audição até a idade de 5 a 6 anos; entretanto, dados disponíveis na literatura com relação ao prognóstico neuropsicomotor de crianças que foram assintomáticas ao nascer ainda são escassos $(19,20)$.

Sabe-se que infecção congênita por CMV pode resultar em sequelas importantes como a surdez e o retardo do desenvolvimento neuropsicomotor. Acredita-se que a infecção congênita por CMV seja a principal causa não genética de perda auditiva nos EUA e no norte da Europa. No Brasil, na cidade de Ribeirão Preto, a prevalência de surdez neurossensorial observada nestas crianças foi de $11 \%$, acometendo $50 \%$ das crianças sintomáticas e $6 \%$ das assintomáticas (21).

Embora um grande número de estudos tenha mostrado a associação entre a infecção congênita por CMV e a ocorrência de surdez neurossensorial em crianças sintomáticas e assintomáticas, ainda não é bem conhecido a repercussão da citomegalovirose congênita no desenvolvimento neuropsicomotor naquelas crianças consideradas assintomáticas ao nascer. Os valores prognósticos de sinais clínicos, achados de neuroimagens e parâmetros laboratoriais em crianças com infecção congênita por CMV têm sido avaliados em estudos americanos e europeus $(22,23)$. Entre as crianças com infecção sintomática por CMV, a microcefalia, coriorretinite, achados neurológicos anormais, surdez neurossensorial, petéquias e plaquetopenia podem estar associadas com prognóstico desfavorável $(24,25,26)$; entretanto, em crianças consideradas assintomáticas, identificadas em uma triagem neonatal, estes fatores de prognóstico ainda não estão bem definidos. 
Tem sido mostrado que a replicação do CMV no sistema nervoso central (SNC) resulta em uma infecção persistente nos neurônios e células progenitoras nas regiões periventriculares que são os principais sítios para o desenvolvimento cerebral, sugerindo que distúrbios cerebrais podem ocorrer após o nascimento em crianças com infecção congênita como resultado da persistência da replicação viral ou pela reativação intermitente do vírus latente nas células cerebrais (24). Como consequência, as crianças, embora assintomáticas ao nascimento, poderiam desenvolver a surdez neurossensorial ou anormalidades neurológicas nos primeiros 4 a 6 anos de vida $(24,27,28)$.

Baseado nos estudos americanos, aproximadamente $2 / 3$ das crianças sintomáticas apresentam ao nascer neuroimagens anormais incluindo calcificações cerebrais, especialmente periventriculares, ventriculomegalia, alterações de substância branca periventricular, anormalidades de migração neuronal como a microgiria, atrofia cortical, cistos periventriculares e hipoplasia cerebelar $(18,23,29,30)$. Noyola et al., 2001, em estudo realizado nos Estados Unidos, mostraram que os achados clínicos ao nascimento mais comumente associados com maior risco de sequelas em crianças sintomáticas incluem a microcefalia e alterações no exame tomográfico de crânio. Ainda segundo estes autores, a presença de alterações na tomografia computadorizada (TC) de crânio e /ou microcefalia prediz a ocorrência de atraso do desenvolvimento neuropsicomotor em $90 \%$ das crianças sintomáticas. Em contraste, mesmo na presença de achados clínicos anormais ao nascimento, crianças com perímetro cefálico e tomografia de crânio normal ao nascimento evoluíram com desenvolvimento cognitivo adequado.

A TC de crânio é altamente sensível para a detecção de calcificações e outras anormalidades cerebrais (30). No entanto, não é a melhor ferramenta para detectar distúrbios de migração neuronal e definir anormalidades de substância branca. Adicionalmente, ainda existe uma grande preocupação com a exposição à radiação ionizante, especialmente em crianças (15).

Nos últimos anos, a neurossonografia transfontanelar (NTF) e a ressonância magnética cerebral (RMc) têm sido muito utilizados para avaliar lesão cerebral em crianças infectadas por CMV (31,32). A presença de alterações na ultrassonografia fetal tem sido considerada como altamente sugestiva de prognóstico neurológico ruim nestas crianças. A RMc é considerada mais sensível que a TC de crânio para identificar anormalidades da substância branca, malformações corticais, áreas de gliose, cistos periventriculares e hipoplasias do hipocampo; entretanto, o papel destas anormalidades, identificadas mais frequentemente pela ressonância magnética, no prognóstico neurológico ainda não é bem conhecido. $(33,34)$ 
O diagnóstico precoce da infecção congênita por CMV torna-se importante tanto para intervenção terapêutica, minimizando morbidade e mortalidade nos recém nascidos (RN) sintomáticos, quanto para a determinação de risco de sequelas futuras nos $\mathrm{RN}$ assintomáticos. O isolamento viral em cultura de fibroblastos humanos é o método convencional para diagnóstico. O vírus geralmente está presente na urina com elevados títulos, principalmente na infecção congênita sintomática por CMV, e as culturas são comumente positivas após três a cinco dias. A reação em cadeia da polimerase (PCR) que permite a detecção do DNA viral é um método alternativo para urina ou outra amostra clínica, apresentando sensibilidade e especificidade semelhante ao isolamento viral e possuindo vantagens sobre o isolamento, tais como a rapidez do resultado (em menos de 24 horas) e a possibilidade de as amostras serem congeladas e armazenadas (35).

\subsection{Justificativas para a realização do estudo}

Os aspectos clínicos e epidemiológicos da infecção congênita por CMV são conhecidos por diferirem de acordo com as condições socioeconômicas e localizações geográficas. Os seguintes pressupostos motivaram a realização deste estudo:

1. Os critérios utilizados para definição de infecção sintomática por CMV são muito variáveis em diferentes estudos. O impacto clínico e consequentemente o peso da doença congênita por CMV tem sido exploradas desde a década de 70 em países europeus e americanos; entretanto, existem dados limitados em países considerados ainda em desenvolvimento como o Brasil.

2. A avaliação clínica ao nascimento complementada com exames de neuroimagens, especificamente a NTF em todas as crianças infectadas congenitamente por este vírus poderá contribuir para a identificação precoce de crianças infectadas com risco para desenvolvimento de potenciais anormalidades neurológicas futuras.

3. As alterações tardias relatadas em crianças com infecção congênita por CMV aparentemente assintomáticas podem ser secundárias às lesões do sistema nervoso central presentes ao nascimento e não identificadas clinicamente ainda no período neonatal. A proporção de crianças sintomáticas poderá ser maior à relatada em estudos anteriores disponíveis na literatura.

4. Os resultados deste estudo poderão contribuir na determinação de preditores de prognóstico e indicadores de tratamento com drogas antivirais no período neonatal em crianças com infecção congênita sintomática e assintomática por CMV. 


\subsection{Revisão da Literatura}

\subsubsection{Principais repercussões clínicas da infecção congênita por CMV}

Aproximadamente $10 \%$ das crianças infectadas intraútero terão sintomas ao nascer, apresentando a doença congênita por CMV que inclui as seguintes manifestações: retardo do crescimento intrauterino, prematuridade, icterícia colestática, hepatoesplenomegalia, púrpura, plaquetopenia, pneumonite intersticial e as manifestações neurológicas: microcefalia, calcificações intracranianas, crises convulsivas no período neonatal, coriorretinite e deficiência de acuidade visual e auditiva $(4,14,36)$.

A perda auditiva causada pelo CMV é atualmente a principal causa de surdez neurossensorial não hereditária em crianças $(24,37)$. A infecção congênita por CMV está associada com 10 a $60 \%$ de todos casos de surdez neurossensorial em crianças (24).

A perda auditiva causada pelo CMV pode estar presente ao nascimento ou ser tardia, de natureza progressiva, com deterioração da audição ao longo dos primeiros anos de vida (24). A natureza progressiva da deficiência auditiva sugere que possa haver uma replicação viral crônica no SNC ou labirinto que continue ativa durante toda a infância. Alguns estudos têm sugerido que a quantificação da carga viral do CMV, ou seja, o limiar de replicação viral em crianças assintomáticas pode ser um preditor da ocorrência de surdez neurossensorial nestas crianças (22). Níveis aumentados e maior duração da excreção urinária de CMV em crianças infectadas sintomáticas e assintomáticas, no início da vida, estão associados com o desenvolvimento de perda auditiva. Além disso, as crianças com perda auditiva progressiva continuam a excretar o vírus na urina por mais de 4 anos, o que sugere que o risco de surdez está relacionado com a replicação viral ativa em curso e carga viral elevada em crianças infectadas congenitamente (38).

Alternativamente, a ocorrência de surdez neurosensorial pode refletir uma alteração na expressão de genes do desenvolvimento resultante de infecção intraútero, embora a ausência de anomalias estruturais no labirinto fale contra esta hipótese (24).

Numerosos estudos epidemiológicos têm correlacionado a infecção congênita por CMV com o desenvolvimento de perda auditiva neurossensorial (39), mas os mecanismos inflamatórios virais envolvidos na patogênese ainda não foram esclarecidos.

Acredita-se que a perda auditiva possa ser causada pela labirintite vírus induzida (40). A histologia da orelha interna de crianças infectadas mostra danos às estruturas, incluindo o sistema vestibular endolinfático e os órgãos vestibulares (sáculo e utrículo) e o colapso da membrana 
sacular (40). O dano é restrito às estruturas endolinfáticas, com participação menor da cóclea.(40). Células portadoras de inclusão são vistas no epitélio do saco endolinfático e são positivas para os antígenos de CMV (40). Postula-se que o CMV entre na endolinfa através da estria vascular (41), e compatível com esta hipótese, o DNA viral pode ser detectado na perilinfa por análise de PCR quantitativa (42). Para entender melhor os danos causados por uma infecção de CMV do ouvido interno, modelos animais têm sido amplamente utilizados (24).

A frequência da deficiência auditiva infantil devido ao CMV infecção é entre 0,2 e 1,3/1.000 nascidos vivos (39). O risco é maior entre crianças com infecção por CMV sintomática (30 a 65\%) do que entre aqueles com infecção congênita assintomática (7-15\%).

\subsubsection{Anormalidades das estruturas cerebrais e alterações em neuroimagens secundárias à infecção congênita por CMV}

As anormalidades estruturais do cérebro foram observadas precocemente em estudos de imagem do feto, desde as 28 semanas de gestação, usando imagens de RM ou NTF (24) . Caracteristicamente, as RMc mostram alterações na substância branca, como a perda da camada de zona intermediária, necrose focal e as hemorragias (25). Mais comumente vistas são lesões crônicas devido à infecção, que incluem dilatação do ventrículo, gliose da substância branca, atrofia (perda de volume), cistos no parênquima, cistos ependimários, calcificações, e malformações corticais (mais notavelmente polimicrogiria) (43).

Análises ultrassonográficas fetais entre 22 e 37 semanas de gestação também podem detectar mudanças estruturais no cérebro. Ultrassonografia transvaginal mostra diferentes padrões de anormalidade periventricular (hiper / hipoecogenicidade), adesões ventriculares, formação cística ao redor dos ventrículos, protrusões ependimárias, sulcos anormais e corpo caloso hipoplásico (33). Cistos periventriculares desenvolvem-se durante o segundo trimestre, lesões do cerebelo são provavelmente o resultado de infecção do feto antes de 18 semanas de gestação, e sulcos anormais provavelmente são devidos a lesões entre 18 e 24 semanas (33).

Estudos de imagem fetais são úteis para determinar o tempo e a extensão da infecção fetal, e estes resultados podem, por sua vez ajudar no prognóstico neurológico (44). Neuroimagens neonatais e pós-natais de crianças sintomáticas com CMV estão quase sempre associadas com anormalidades estruturais do cérebro semelhantes aos observados em fetos infectados. A mais frequente delas é a presença de calcificações intracranianas (50\%) (24).

A TC de crânio no período neonatal geralmente mostra outras alterações anormais, tais como a ventriculomegalia, alterações de substância branca, polimicrogiria, cistos, anomalias 
estruturais e encefalopatia extensa (30). Outras anormalidades observadas no espectro de neuroimagem/anormalidades patológicas incluem lisencefalia, porencefalia e esquizencefalia.

Resultados anormais de NTF (mostrando calcificações periventriculares ou de parênquima, aumento do tamanho ventricular e lesões do cerebelo) realizadas durante a primeira semana de vida são úteis em crianças sintomáticas para predizer o desenvolvimento de algum déficit neurológico na vida $(32,45)$.

Normalmente, as crianças assintomáticas não mostram extensas calcificações ou ventriculomegalia acentuada (46). A presença de padrões distintos, mas sutis de lesões da substância branca visíveis na RMc, com ou sem polimicrogiria e em combinação com cistos do lobo temporal é sugestiva de infecção por CMV (34).

A correlação destas lesões de substância branca vistas em imagens de RMc e desenvolvimento de perda auditiva ou outras alterações neurológicas é ainda desconhecida.

Um estudo recente realizado em Israel identificou a vasculopatia lenticuloestriada (VLE) como um achado comum em US de crânio de crianças com infecção congênita sintomática por CMV e um sinal de envolvimento de SNC nestas crianças. Além disso, considerou a mesma como um possível marcador de alto risco para perda auditiva neurossensorial em pacientes com infecção congênita por CMV. A VLE, vista como a imagem de um castiçal quando observada em US cerebral neonatal, refere-se à hiperecogenicidade dos ramos lenticuloestriados da artéria cerebral média, localizada na região do tálamo e gânglios da base. Este achado têm sido encontrado em até 54,3\% dos pacientes com infecção congênita por CMV $(47,48)$. Foi ainda observado que pacientes com VLE como achado único e não tratados, evoluíram com deterioração auditiva $(47,48)$. Neste estudo realizado em uma população de crianças de Israel, devido a à alta frequência destes achados, o protocolo terapêutico do estudo foi modificado e passou-se a tratar estes pacientes. Todos mantiveram a audição normal durante o seguimento. A diferença nas taxas de deterioração auditiva entre pacientes tratados e não tratados foi estatisticamente significante.

\subsubsection{Insuficiência placentária: dano vascular, hipóxia e permeabilidade alterada}

A eficiência de transmissão do CMV nas diferentes fases do desenvolvimento da placenta podem influenciar a infecção fetal. A placenta, barreira que separa as circulações materna e fetal, é progressivamente invadida pelos trofoblastos na decídua materna e, em última análise, ocorre a sua fusão para formar os sinciciotrofoblastos (49). 
Embora haja evidência de que a patogênese relacionada ao CMV seja mediada por infecção direta do feto, estudos recentes têm demonstrado que, enquanto a placenta serve como um reservatório de amplificação e condução eficaz para a transmissão viral, a infecção por CMV de células da placenta também pode contribuir para os danos da infecção congênita por CMV, alterando a formação da placenta e, em última análise, resultando em insuficiência placentária (50).

Adicionalmente, a infecção por CMV de citotrofoblastos placentários pode alterar perfil de expressão gênica da célula infectada. O momento da infecção durante a gestação poderia determinar o acometimento fetal associado com a insuficiência placentária. A infecção durante o primeiro trimestre das vilosidades coriônicas (49) pode afetar adversamente o desenvolvimento da placenta. A infecção dos trofoblastos no início da gestação pode prejudicar a implantação adequada e, portanto, resultar em aborto. Nos estágios mais avançados da gravidez, o desenvolvimento inadequado da placenta pode resultar em restrição do crescimento intrauterino e outros resultados fetais decorrentes da insuficiência placentária $(49,51)$.

As alterações anatomopatológicas da placenta estão fortemente associadas com a doença fetal e neonatal (51). É plausível que algumas das características clínicas da doença de inclusão citomegálica poderiam ser explicadas por hipóxia fetal resultantes da insuficiência placentária e hipoperfusão e não exclusivamente da ação direta da replicação viral, o que poderia, por sua vez contribuir para a patogênese de anormalidades cerebrais, como polimicrogiria (51).

\subsubsection{Alterações oculares da infecção congênita por CMV}

A manifestação principal é a coriorretinite com estrabismo e atrofia óptica. Como a coriorretinite pode ocorrer também em outras infecções congênitas como a toxoplasmose, a lesão não pode ser diferenciada com base no aspecto ou localização. Ao contrário da toxoplasmose congênita, a progressão pós-natal da coriorretinite é incomum na citomegalovirose congênita. As outras lesões tais como a microftalmia, catarata, necrose e calcificação da retina, perda visual grave, malformações do globo ocular e vestígio de membrana pupilar são observadas mais raramente e descritos em associação à forma da citomegalovirose congênita generalizada (52). 


\subsubsection{Uso dos antivirais para tratamento da infecção congênita pelo CMV}

As indicações atuais de tratamento com droga antiviral são ainda baseadas nos resultados da fase III de um estudo clínico multicêntrico controlado realizado nos Estados Unidos (53). Este estudo comparou crianças que receberam tratamento com o ganciclovir, 6 $\mathrm{mg} / \mathrm{kg} /$ dose de $12 \mathrm{em} 12$ horas durante 6 semanas com aquelas que receberam placebo. Observou-se neste estudo que 21/25 (84\%) crianças tratadas melhoraram a audição ou mantiveram audição normal com 6 meses de idade comparadas com 10/17 (59\%) crianças não tratadas. Aos 6 meses de idade, nenhuma das 25 crianças tratadas tiveram piora da audição contra 7/17 (41\%) dos controles, sendo que com 1 ano de idade essa proporção era de $21 \%$ para as crianças tratadas e de $68 \%$ para as crianças não tratadas. A despeito de uma perda significativa de pacientes durante o seguimento (53\% no grupo de estudo vs $35 \%$ no grupo controle), o que torna esses dados criticáveis, a pesquisa parece ter mostrado evidências que crianças sintomáticas e com envolvimento do sistema nervoso central tratadas com 6 semanas de ganciclovir a partir do período neonatal sejam protegidas da deterioração auditiva aos 6 meses e com 1 ano ou mais de idade. Eventos adversos como a neutropenia foram observados mais frequentemente em crianças tratadas com ganciclovir (63\% vs 21\% no grupo controle). Ainda neste estudo, demonstrou-se que o ganciclovir pode suprimir a replicação viral durante a sua administração. Entretanto, a excreção viral detectável reaparece cerca de 3 semanas após a suspensão da droga (53). Considerando que a detecção do CMV na urina possa refletir a replicação viral em sítios não acessíveis, como na região coclear do ouvido interno, com o objetivo de prevenir a progressão da perda auditiva existem questionamentos sobre a necessidade do tratamento mais prolongado em crianças com citomegalovirose congênita sintomática. A disponibilidade de uma forma oral do ganciclovir (valganciclovir) torna possível verificar se um curso mais longo do que 6 semanas implicaria em maiores benefícios. Estudo farmacocinético mostrou que a dose de $16 \mathrm{mg} / \mathrm{kg}$ do valganciclovir oral promove níveis séricos sistêmicos similares ao do ganciclovir endovenoso, com toxicidade similar. Mais recentemente, o segundo estudo multicêntrico e controlado (54), comparou crianças sintomáticas com ou sem envolvimento do sistema nervoso central, e que receberam valganciclovir na dose de $16 \mathrm{mg} / \mathrm{kg} /$ dose de 12/12 horas, por via oral, durante 6 meses, com aquelas que receberam placebo. A neutropenia com valganciclovir foi menor quando comparado ao ganciclovir endovenoso. Os dados deste segundo estudo controlado sugerem que as crianças com infecção sintomática por CMV e que receberam valganciclovir por 6 meses apresentaram evolução audiológica e neurológica mais favorável quando comparado ao 
grupo placebo. Embora os resultados tenham sido modestos, este regime por via oral tem a vantagem da não necessidade de manutenção do acesso endovenoso e consiste no protocolo atual sugerido para o tratamento de crianças com infecção congênita sintomática.

Quanto a recém-nascidos assintomáticos ou recém-nascidos oligossintomáticos com doença congênita por CMV sem envolvimento do SNC, o tratamento antiviral não é indicado até a data atual, considerando-se os efeitos adversos da droga antiviral e a ausência de comprovação de benefícios. 
2 Objetivos 


\section{OBJETIVOS}

- Objetivos gerais:

Os objetivos gerais deste estudo consistiram em verificar o impacto da infecção congênita sintomática e assintomática por CMV ao nascer, explorando potenciais preditores prognósticos de anormalidades tardias em uma coorte de crianças com infecção congênita por este vírus.

- Objetivos específicos:

1. Definir a proporção de crianças com infecção congênita por CMV sintomáticas e assintomáticas ao nascer baseado em achados do exame clínico, NTF, avaliação auditiva e laboratorial.

2. Determinar a frequência e características dos achados de NTF em crianças assintomáticas e verificar a sua associação com a ocorrência de surdez neurossensorial.

3. Determinar a frequência de surdez neurossensorial (precoce) relacionada ao CMV no período neonatal em crianças sintomáticas e assintomáticas.

4. Verificar a associação entre a carga viral do CMV na urina com a ocorrência de surdez neurossensorial e/ou anormalidades nos exames de NTF. 
3 Métodos 


\section{MÉTODOS}

\section{Desenho do estudo:}

A população de estudo foi constituída por uma coorte de crianças com diagnóstico confirmado de infecção congênita por CMV identificadas em uma triagem neonatal desta infecção no Hospital das Clínicas da Faculdade de Medicina de Ribeirão Preto, Universidade de São Paulo, Brasil - HCFMRP-USP - e no Centro de Referência em Saúde da Mulher CRSM-Mater, no período de janeiro de 2014 a agosto de 2016. Aproximadamente 9.500 bebês nascem a cada ano na cidade de Ribeirão Preto. O total de 5.000 (56\%) nascem nesses dois hospitais anualmente.

O HCFMRP-USP oferece tratamento obstétrico para gestações de alto e médio risco para parturientes dessa região. Aproximadamente 1.800 bebês/ano nascem nessa unidade e cerca de $40 \%$ das mulheres que dão à luz nesse hospital são de Ribeirão Preto e recebem tratamento pré-natal em clínicas comunitárias como parte do Sistema Único de Saúde (SUS). As mulheres são hospitalizadas por 24 a 48 horas após o parto normal sem complicações.

O segundo hospital, CRSM-Mater, oferece tratamento para parturientes de baixo risco e é um importante local para o parto de gestantes acompanhadas em unidades básicas de saúde de Ribeirão Preto. As características demográficas da população de parturientes são semelhantes ao HCFMRP-USP. Dos 3.000 bebês nascidos a cada ano no CRSM-Mater, 80\% (2.400) das mães são de Ribeirão Preto, sendo o tratamento pré-natal semelhante ao do HCFMRP-USP.

A taxa de soroprevalência ao CMV nesta população materna foi de $97 \%$, em estudo realizado em amostra representativa de gestantes que receberam pré-natal nos serviços de assistência básica à saúde do SUS (16).

O projeto foi aprovado pelo Comitê de Ética, Processo HCFMRP-USP (15905/2011), Anexo 1.

\subsection{Definição de infecção congênita por CMV}

A triagem da infecção congênita por CMV consistiu de obtenção de amostras de saliva de todos os RN nas primeiras 3 semanas de vida para detecção do DNA do CMV pela PCR. A infecção congênita por CMV foi definida ao nascimento nestas crianças pela presença do vírus em duas amostras de saliva e uma de urina , obtidas de cada criança nas primeiras 3 semanas de vida, pela detecção do DNA do CMV pela PCR. 


\subsection{Avaliação das crianças com infecção congênita confirmada por CMV}

Todas as crianças quando identificadas como infectadas foram avaliadas ao nascimento por meio de exame físico detalhado, avaliação auditiva objetiva pelo potencial evocado da audição (PEATE) e fundoscopia ocular.

A avaliação do SNC foi realizada pela NTF e quando alterada, pela RMc, sendo ambos os exames realizados na Divisão de Radiologia do HCFMRP-USP. O protocolo dos exames de NTF seguiu um padrão internacional e incluiu um conjunto de imagens adquiridas com um transdutor linear de alta freqüência $(9-11 \mathrm{MHz})$ utilizando os equipamentos equipamento GE do modelo E9 ou modelo portátil Logic E. As imagens foram examinadas por dois neurorradiologistas com experiência em imagens neonatais, de maneira independente e as divergências foram discutidas e resolvidas em consenso. Foram considerados achados anormais a presença de calcificações periventriculares ou parenquimatosas, cistos subependimários de etiologia não hemorrágica, a vasculopatia lenticuloestriada (VLE) e a dilatação ventricular. As calcificações foram caracterizadas por hiperecogenicidade periventricular bilateral com sombra acústica ou focos hiperecoicos no parênquima cerebral com ou sem sombra acústica. Os cistos subependimários foram definidos pela presença de lesões císticas localizadas medialmente à cabeça do núcleo caudado, abaixo dos ângulos externos dos cornos frontais e posterior ou ao nível do forame de Monro, dentro das regiões da matriz germinal subependimária. A VLE foi definida pela presença de pelo menos uma bifurcação ou duas estrias hiperecogênicas ou calcificações lineares de ambos os lados dos gânglios da base ou tálamo.

Os exames de RM de encéfalo foram realizados no aparelho 3.0 Tesla, marca Philips, modelo Achieva X-series, com sequências otimizadas para alta resolução espacial e de contraste, nos 3 planos ortogonais incluindo todo o encéfalo, sem a administração de contraste. As seguintes alterações foram consideradas como achados sugestivos de infecção congênita: cistos periventriculares localizados no lobo temporal anterior, calcificações geralmente periventriculares (baixo sinal nas sequências em T2 e alto em T1), ventriculomegalia leve a moderada, cistos periventriculares, alterações de migração cortical com polimicrogiria, alterações de substância branca periventricular com alto sinal nas sequências T2, que frequentemente pode ser caracterizada por lesão cística e a hipoplasia cerebelar.

Adicionalmente, parâmetros laboratoriais para avaliação hematológica com contagem de plaquetas e avaliação da função hepática foram realizadas. Alterações de exames 
laboratoriais foram caracterizadas por contagem de plaquetas menor que $100 \times 10^{3} / \mathrm{ml}$ ), aumento de pelo menos duas vezes dos valores de AST ou TGO (aspartato transaminase), ALT ou TGP (alanina transaminase) e gama glutamil transferase (rGT).

Todos estes dados foram relatados em formulários do estudo, como mostram o Anexo 2: Registros médicos iniciais (BF101), Avaliação do exame físico (BF102) e Resultados laboratoriais (LB103).

A doença congênita sintomática por CMV ao nascer foi definida naquelas crianças que apresentaram uma ou mais das seguintes anormalidades clínicas: hepato e/ou esplenomegalia, icterícia com aumento da bilirrubina direta, colestase neonatal, petéquias com plaquetopenia, microcefalia definida por perímetro cefálico menor que 2 desvios padrões do normal para idade, e/alterações na fundoscopia ocular (20,30). A presença de surdez neurossensorial ao nascimento foi considerada como seqüela e não manifestação clínica da doença congênita por CMV.

Nas crianças sintomáticas ao nascer foram excluídas outras causas de infecção congênita, tais como a infecção congênita por Toxoplasma gondii, pelo vírus da rubéola, por Treponema palllidum e, em casos selecionados, pelo Parvovírus B19, enterovírus e Herpes simplex 1 e 2 .

\subsection{Avaliação audiológica das crianças infectadas por CMV}

As crianças foram testadas em duas etapas: o teste de otoemissão acústica (OEA) como parte da triagem auditiva universal, realizado antes da alta hospitalar e o Potencial Evocado Auditivo de Tronco Encefálico (PEATE) automático, realizado no momento em que a criança foi identificada como infectada congenitamente pelo CMV (antes de três semanas de vida). Todas as crianças infectadas foram submetidas ao diagnóstico audiológico com a idade de 3 a 6 semanas de vida. A avaliação e diagnóstico audiológicos consistiram em procedimentos fisiológicos, eletrofisiológicos e eletroacústicos de mensuração da função auditiva, incluindo as Emissões Otoacústicas Evocadas por Transiente e/ou Produto de Distorção, Potencial Evocado Auditivo de Tronco Encefálico (PEATE) para pesquisa da função neural (estímulo click) e estimativa de limiar eletrofisiológico (estímulo tone burst de 500, 1000, 2000 e 4000Hz); medidas da imitância acústica e avaliação clínica do comportamento auditivo do bebê. Na identificação da perda auditiva, as crianças foram acompanhadas para receberem a 
intervenção e reabilitação adequadas e precoces. Todo esse processo garantiu que a criança com perda auditiva permanente fosse diagnosticada até o $3^{0}$ mês de vida e recebesse intervenção e reabilitação adequada até o 6o mês de vida.

Todas as crianças infectadas por CMV foram monitoradas com seguimento audiológico como mostra a Tabela 1:

Tabela 1. Protocolo de monitoramento audiológico de crianças selecionadas para seguimento

\begin{tabular}{|c|c|}
\hline & Procedimentos Audiométricos \\
\hline $\begin{array}{l}\text { Avaliação com 3-6 } \\
\text { semanas de vida }\end{array}$ & $\begin{array}{l}\text { - BERA, tone bursts e teste de condução por via óssea se } \\
\text { indicado (reflete a atividade da cóclea, do nervo coclear e } \\
\text { das vias auditivas do tronco encefálico) } \\
\text { - Medidas de imitância acústica: } \\
\text { a. Timpanometria, } \\
\text { b. Reflexos Acústicos } \\
\text { - Emissões otoacústicas evocadas por transiente e/ou produto } \\
\text { de distorção(sensível à disfunção da célula ciliada externa); }\end{array}$ \\
\hline $\begin{array}{l}\text { Visitas } \operatorname{com} 7,12, \\
18,24,30,36,42- \\
48 \text { meses }\end{array}$ & $\begin{array}{l}\text { - Audiometria comportamental (reforço visual [VRA] ou } \\
\text { Lúdica) por condução aérea e condução por via óssea, se } \\
\text { indicado; } \\
\text { - Audiometria lúdica. } \\
\text { - Medidas da imitância acústica: } \\
\text { a. Timpanometria, } \\
\text { b. Reflexos Acústicos do Músculo Estapédio; } \\
\text { - Emissões otoacústicas evocadas por transiente e/ou produto } \\
\text { de distorção; } \\
\text { - PEATE, se indicado; }\end{array}$ \\
\hline
\end{tabular}

\subsection{Ensaios laboratoriais}

As amostras de saliva e/ou de urina foram processadas para detecção do DNA viral sem extração prévia, apenas fervidas a $94 \square$ C por 6 minutos.

Todas as amostras clínicas obtidas das crianças participantes foram submetidas à PCR convencional, com resultado qualitativo. Para a amplificação, foram utilizados 2 pares de iniciadores, sendo um que amplifica uma região do gene UL 123 do CMV (CMV1-UL123: 5'-CAAGCGGCCTCTGATAACCAAGC-3' e CMV2-UL123: 5'-CTCTTCCTCTGGGGCA ACTTCCTC-3') e o outro que amplifica uma região do gene codificador da glicoproteína B do CMV, (gB-1319; 5'TGGAACTGGAACGTTTGGC3' e gB-1676; 5'TGACGCTGGTT 
TGGTTGAATG3'). A 2,5 $\mu 1$ do controle positivo do CMV (amostra clínica previamente testada contendo o DNA do CMV), controle negativo (água deionizada) e 2,5 $\mu 1$ de amostra clínica teste, é adicionado uma mistura de reação contendo tampão 1 vez concentrado (Green $\mathrm{GO}^{\circledR}$ Taq Flexi Buffer), 1.5mM MgCl2, 0.2mM de cada dNTP, $15 \mathrm{pmol}$ de cada um dos pares de iniciadores ou primers (vide Tabela 1), 1.25 unidades de Taq DNA Polimerase (PROMEGA, USA), em um volume final de $25 \mu$ l. Inicialmente, as misturas são submetidas à desnaturação a $95^{\circ} \mathrm{C}$, por $4 \mathrm{~min}$, em termociclador (Eppendorf, USA). Em seguida, são realizados 35 ciclos térmicos, a $94^{\circ} \mathrm{C}$ por $30 \mathrm{seg}, 60^{\circ} \mathrm{C}$ por $1 \mathrm{~min}$ e $72^{\circ} \mathrm{C}$ por $1 \mathrm{~min}$. Ao final, as misturas serão incubadas a $72 \square \mathrm{C}$, por $5 \mathrm{~min}$, para completar a extensão.

Para a visualização dos produtos amplificados, $10 \mu \mathrm{l}$ dos produtos obtidos pela PCR são analisados em gel de agarose a 2\% corado com GelRed (BIOTIUM/UNISCIENCE DO BRASIL) 1 vez concentrado, após eletroforese a $150 \mathrm{~V}$, por $40 \mathrm{~min}$, em solução tampão TBE (Tris 0,1M, Ácido Bórico 0,1M, EDTA 0,02M pH 8,3). Posteriormente, os géis são fotografados em sistema de fotodocumentação L.PIX (Loccus Biotecnologia). O tamanho do produto amplificado de 438 pares de base (pb) com os iniciadores UL123 e de 298 bp foi determinado por comparação com um marcador de 100 pb. Em todas as reações foram utilizados controles positivos, que são suspensões virais contendo a cepa laboratorial do CMV. Amostras de água deionizada foram utilizadas como controles negativos.

As amostras clínicas das crianças nas quais o DNA viral foi detectado ao nascimento, foram submetidas à PCR em tempo real, para quantificação absoluta do $\mathrm{CMV}$, utilizando a metodologia de sonda hidrolisável TaqMan-MgB, com primers que amplificam parte do exon 4 do gene MIEA (major immediate early antigen) do CMV (HCMV UL123). O DNA do CMV foi extraído das amostras de urina e de saliva previamente à amplificação. O produto amplificado ou DNA alvo foi detectado por meio de uma sonda específica marcada com corante fluorescente para uma única sequência genômica do CMV, e quantificado a partir da comparação com a curva padrão gerada a partir de padrões com numero de copias conhecidas, para a determinação da carga viral por extrapolação logaritmica. Um Controle Interno foi utilizado para cada amostra processada individualmente, para identificação da presença de possíveis inibidores. O limite de detecção (LOD) deste ensaio é de 0,57 cópias $/ \mu \mathrm{L}$. O limite máximo de quantificação é 5,30 $\log 10(2 \mathrm{E}+05$ cópias/ $\mu \mathrm{L})$ e o limite mínimo de quantificação é $0,0 \log 10(1 \mathrm{E}+00$ cópias/uL). Os ciclos térmicos para amplificação consistiram de uma fase de descontaminação de 2 minutos a $50^{\circ} \mathrm{C}$, uma desnaturação inicial a $95^{\circ} \mathrm{C}$ por 10 minutos e 50 ciclos de desnaturação a $95^{\circ} \mathrm{C}$ por 15 segundos e $60^{\circ} \mathrm{C}$ por 1 minuto. Os resultados foram expressos em copias do DNA alvo/ml e em $\log 10$. 


\subsection{Análise de dados}

Considerando as 66 crianças com infecção congênita por CMV, sintomáticas e assintomáticas, foi realizada uma análise de regressão logística uni e multivariada para verificar a associação entre as alterações de exames laboratoriais, alterações de NTF/RMc e presença de sintomas ao nascer com a ocorrência de surdez (presença ou ausência). Verificou-se também a associação entre as alterações de exames laboratoriais com os achados anormais de NTF/RMc (presença ou ausência). A análise multivariada dos fatores de risco foi ajustada pela presença de sintomas ao nascer, uma vez que é esperado que crianças sintomáticas sejam aquelas de maior risco para ocorrência de surdez bem como para apresentarem alterações de NTF/RMc.

Considerando apenas as 53 crianças sem achados clínicos ao nascer ou assintomáticas, foi realizada uma análise de regressão logística univariada para verificar a associação entre as alterações de exames laboratoriais e de neuroimagens com a ocorrência de surdez. Estimativa do risco relativo (RR) e seus intervalos de confiança (95\% IC) foram obtidos utilizando o procedimento do “software” SAS 9.3. (55).

A análise da curva ROC (curva de características de operação do receptor) foi utilizada para avaliar a capacidade da carga viral como preditor da ocorrência de sinais clínicos ao nascer, achados anormais de NTF e/ou RMc e surdez relacionados ao CMV. O poder discriminatório pela determinação do ponto de corte do valor da carga do DNA do CMV foi avaliada pela área abaixo da curva (AUC) e os valores de sensibilidade e especificidade para cada ponto de corte da carga viral foram determinados (56). 
4 Resultados 


\section{RESULTADOS}

A triagem neonatal da infecção congênita pelo CMV compreendeu o período de Outubro de 2013 a Agosto de 2016, com um total de 11957 recém nascidos triados, nascidos no HCFMRP no CRSM - Mater.

Do total de 11957 recém-nascidos, 66 (0,55\% ; IC 95\%: 0,44-0,70) crianças foram identificadas como infectadas congenitamente pelo CMV. Dois desses recém-nascidos evoluíram para óbito. A Tabela 2 mostra as principais características de todos os recémnascidos participantes da triagem neonatal desta infecção e de crianças identificadas como infectadas congenitamente pelo CMV.

Das 66 crianças portadoras de infecção congênita por CMV, 35 (53\%) eram do sexo masculino e $31(47 \%)$ do sexo feminino, $46(69,7 \%)$ eram brancos, $18(27,3 \%)$ mulatos e 2 (3\%) eram negros. Quanto à idade gestacional 15/66 (22,7\%) eram prematuros. Quanto ao tipo de parto, 39 (59\%) crianças nasceram de parto vaginal e 27 (41\%) de cesárea. A mediana do peso ao nascer foi de 2945g (530-3865); do comprimento $48 \mathrm{~cm}$ (29-53) e do perímetro cefálico foi de $33 \mathrm{~cm}(21,5-36,5)$. Apenas 2 dos 66 (3\%) pacientes tiveram Apgar menor que 7 no quinto minuto de vida.

Os sinais clínicos sugestivos de infecção congênita ao nascer foram observados em 8/66 (12,1\%; IC95\%: 5,74-23,03), sendo considerados sintomáticos.

A Figura 1 mostra a proporção de crianças sintomáticas e aquelas consideradas assintomáticas, de acordo com a presença ou ausência de manifestações clínicas ao nascer. A plaquetopenia com ou sem petéquias, a hepatoesplenomegalia e a colestase neonatal foram os achados mais frequentes em crianças sintomáticas, como mostra a Tabela 3. 
Tabela 2. Características dos RN triados para a detecção da infecção congênita pelo CMV no HC-FMRP e CRSM-Mater, no período de outubro de 2013 a agosto de 2016, e daqueles detectados como infectados congenitamente pelo vírus.

\begin{tabular}{|c|c|c|}
\hline $\begin{array}{l}\text { Características dos } \\
\text { recém-nascidos }\end{array}$ & $\begin{array}{l}\text { População de } 11957 \text { participantes da } \\
\text { triagem neonatal para CMV } \\
\text { N= } 11957(100 \%)\end{array}$ & $\begin{array}{c}\text { População de } 66 \text { pacientes } \\
\text { infectados por CMV } \\
\mathrm{N}=66(0,55 \%)\end{array}$ \\
\hline \multicolumn{3}{|l|}{ Sexo } \\
\hline $\begin{array}{l}\text { Masculino } \\
\text { Feminino } \\
\text { Indeterminado }\end{array}$ & $\begin{array}{c}6219(\mathbf{5 2 \%}) \\
5730(\mathbf{4 7 , 9 \% )} \\
8(\mathbf{0 , 1 \% )}\end{array}$ & $\begin{array}{c}35(\mathbf{5 3 \%}) \\
31(\mathbf{4 7 \%}) \\
0(\mathbf{0 \%})\end{array}$ \\
\hline \multicolumn{3}{|l|}{ Gemelar } \\
\hline $\begin{array}{l}\text { Sim } \\
\text { Não }\end{array}$ & $\begin{array}{c}549(\mathbf{4 , 6 \% )} \\
11408(\mathbf{9 5 , 4 \% )}\end{array}$ & $\begin{array}{c}3(\mathbf{4 , 5 \% )} \\
63(\mathbf{9 5 , 5 \% )}\end{array}$ \\
\hline \multicolumn{3}{|l|}{ Peso (g) } \\
\hline $\begin{array}{l}\text { Mediana } \\
\text { (mín-máx) } \\
\text { Média }\end{array}$ & $\begin{array}{c}\mathbf{3 1 7 5} \\
(460-5440) \\
3108,2\end{array}$ & $\begin{array}{c}\mathbf{2 9 4 5} \\
(530-3865) \\
2783,8\end{array}$ \\
\hline \multicolumn{3}{|l|}{ Mãe com HIV } \\
\hline $\begin{array}{l}\text { Sim } \\
\text { Não } \\
\text { Desconhecido }\end{array}$ & $\begin{array}{c}122(\mathbf{1 \%}) \\
11819(\mathbf{9 8 , 9 \% )} \\
16(\mathbf{0 , 1 \% )}\end{array}$ & $\begin{array}{c}0(0 \%) \\
66(100 \%) \\
0(0 \%)\end{array}$ \\
\hline \multicolumn{3}{|l|}{ Id Gestacional } \\
\hline $\begin{array}{l}<37 \text { sem } \\
>\text { ou }=37 \text { sem } \\
\text { Desconhecida }\end{array}$ & $\begin{array}{c}1623(\mathbf{1 3 , 6 \% )} \\
10316(\mathbf{8 6 , 3 \% )} \\
18(\mathbf{0 , 1 \% )}\end{array}$ & $\begin{array}{c}15(\mathbf{2 2 , 7 \% )} \\
51(\mathbf{7 7 , 3 \% )} \\
0(\mathbf{0 \%})\end{array}$ \\
\hline \multicolumn{3}{|l|}{ Tipo de parto } \\
\hline $\begin{array}{l}\text { Vaginal } \\
\text { Cesáreo }\end{array}$ & $\begin{array}{l}7897(\mathbf{6 6 , 1 \%}) \\
4060(\mathbf{3 3 , 9 \% )}\end{array}$ & $\begin{array}{l}39(\mathbf{5 9 \%}) \\
27(\mathbf{4 1 \% )}\end{array}$ \\
\hline \multicolumn{3}{|l|}{ Apgar } \\
\hline $\begin{array}{l}<7 \text { no } 5^{\circ} \min \\
>=7 \text { no } 5^{\circ} \mathrm{min} \\
\text { Desconhecido }\end{array}$ & $\begin{array}{c}216(\mathbf{1}, \mathbf{8 \%}) \\
11696(\mathbf{9 7 , 8 \% )} \\
45(\mathbf{0 , 4 \% )}\end{array}$ & $\begin{array}{c}2(3 \%) \\
64(\mathbf{9 7 \% )} \\
0(\mathbf{0 \% )}\end{array}$ \\
\hline \multicolumn{3}{|l|}{ Raça } \\
\hline $\begin{array}{l}\text { Branco } \\
\text { Asiático } \\
\text { Mulato } \\
\text { Negro }\end{array}$ & $\begin{array}{c}8756(\mathbf{7 3 , 2 \% )} \\
9(\mathbf{0 , 1 \% )} \\
2772(\mathbf{2 3 , 2 \% )} \\
420(\mathbf{3 \%}) \\
\end{array}$ & $\begin{array}{c}46(\mathbf{6 9 , 7 \%}) \\
0(\mathbf{0 \%}) \\
18(27,3 \%) \\
2(3 \%) \\
\end{array}$ \\
\hline
\end{tabular}


Figura 1: Proporção de crianças infectadas congenitamente pelo CMV com presença e ausência de achados clínicos ao nascer.

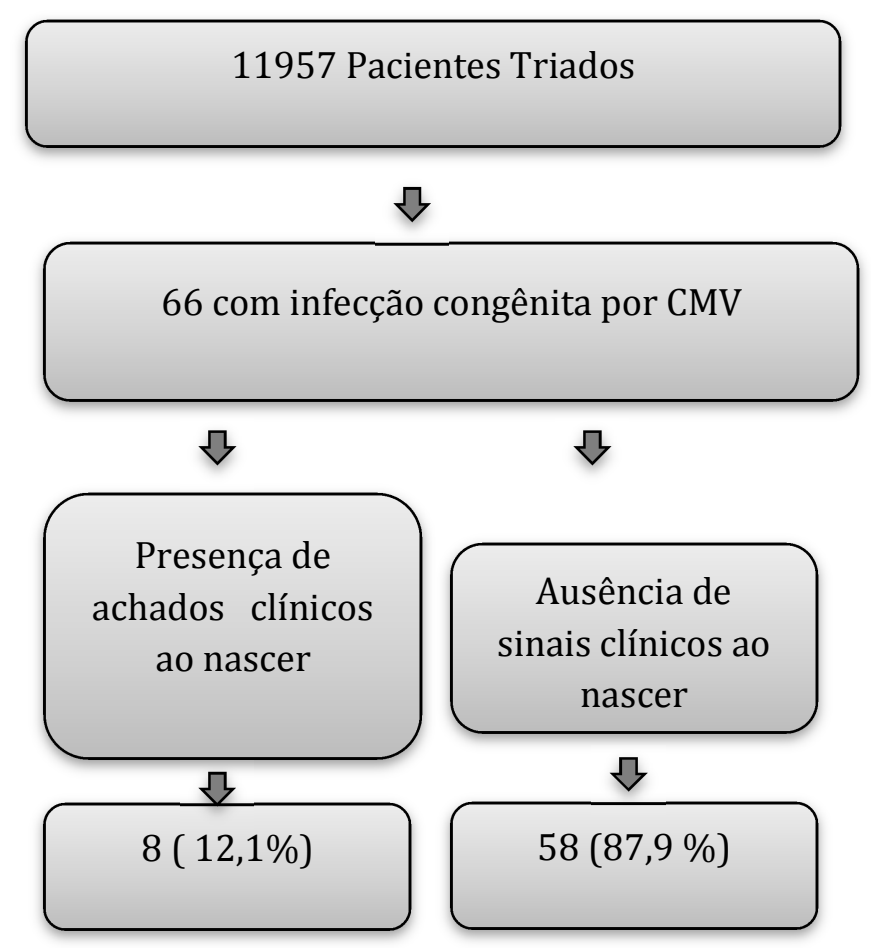

Tabela 3: Principais achados clínicos ao nascer observados em crianças sintomáticas com infecção congênita por CMV.

Colestase $(\mathrm{BD}>20 \%)$ 
As alterações oculares foram observadas em 3/8 (37,5\%) crianças sintomáticas, sendo um caso de turvação vítrea bilateral, um de atrofia macular unilateral e outro de hiperpigmentação retiniana com acúmulo de pigmento em mácula. Com relação às crianças assintomáticas, $1 / 58(1,7 \%)$ apresentou lesão ocular, caracterizada por coriorretinite cicatrizada em pólo posterior de ambos os olhos.

A surdez neurossensorial identificada ao nascer, foi observada em 8/66 (12,2\%; IC95\%: 5,74-23,03\%) crianças. Destas crianças, 4 eram assintomáticas ao nascer e apresentaram perda auditiva unilateral profunda (maior que 90 dbNA) e 4 eram sintomáticas ao nascer, com surdez profunda bilateral. Desta maneira, a surdez neurossensorial relacionada ao CMV foi observada em 4/58 (6,9\%; IC95\%: 2,23- 17,54\%) e em 4/8 (50\%; IC95\%: 17,44-82,55 \%) crianças assintomáticas e sintomáticas, respectivamente.

Todas, com exceção de uma criança sintomática, apresentaram alterações nos exames de NTF; entretanto, os achados em uma criança consistia de alterações encontradas comumente em prematuros, caracterizada por hemorragia periventricular grau II bilateralmente. $\mathrm{O}$ exame não foi repetido porque a criança evoluiu para óbito. Os achados anatomopatológicos desta criança eram sugestivos de infecção viral disseminada. Desta maneira, as anormalidades de NTF sugestivas de infecção congênita foram observadas em 7 de 8 crianças sintomáticas (87,5\%; IC95\%: 46,67-99,34\%). Os achados mais frequentes foram as calcificações intracranianas periventriculares $5 / 7$ (71,4\%), os cistos subependimários 4/7 (57,1\%), a ventriculomegalia 4/7 (57,1\%), hiperecogenicidade de substância branca 3/7 (42,8\%), alterações de migração neuronal (polimicrogiria frontal e nos lobos temporais) 3/7 (42,8\%); vasculopatia lenticuloestriada $1 / 7(14,2 \%)$ e leucomalácia periventricular 1/7 $(14,2 \%)$.

Dentre as 58 assintomáticas, 53 foram avaliadas por meio de NTF e 5 não foram avaliadas por faltas subsequentes e apesar de tentativas de remarcação, ainda não foram submetidas a esta investigação. Do total de 53 crianças avaliadas, 30/53 apresentaram alterações em NTF, sendo que uma criança com anóxia neonatal grave apresentava áreas de necrose neuronal difusa, evoluindo com encefalomalácia multicística. Alterações sugestivas de infecção congênita foram identificadas em 29/52 (55,7\%; IC95\%: 41,41-69,27\%).

A Tabela 4 mostra os achados ultrassonográficos encontrados em 29 crianças consideradas assintomáticas ao nascer, ou seja, aquelas que não apresentavam nenhuma manifestação clínica ao nascer. 
Tabela 4: Principais achados na NTF sugestivos de infecção congênita por CMV observados em crianças consideradas assintomáticas ao nascer.

\begin{tabular}{lc}
\hline Achados observados & Frequência (\%) \\
\hline Vasculopatia lenticuloestriada associada ou não a cistos & $13 / 29(43,3 \%)$ \\
subependimários & $11 / 29(37,9 \%)$ \\
Cistos subependimários & $4 / 29(13,8 \%)$ \\
Calcificação única ou calcificações periventriculares & $4 / 29(13,8 \%)$ \\
Ventriculomegalia & \\
\hline
\end{tabular}

As Figuras 2 a 4 mostram alterações observadas em exame ultrassonográfico de uma criança com ausência de sinais clínicos ao nascer. Esta criança nasceu de parto normal, com idade gestacional de 39 semanas, pesando 3050g (adequado para a idade gestacional), com perímetro cefálico de $33 \mathrm{~cm}$. Avaliação auditiva ao nascimento mostrou a presença de surdez profunda neurossensorial à esquerda.A Figura 2 mostra calcificações periventriculares puntiformes e a Figura 3 mostra cistos subependimários bilaterais. A ressonância magnética encefálica mostra ventriculomegalia supratentorial e cistos subependimários, como mostra a Figura 4.

Figura 2: Neurossonografia transfontanelar com imagem de calcificação periventricular puntiforme.
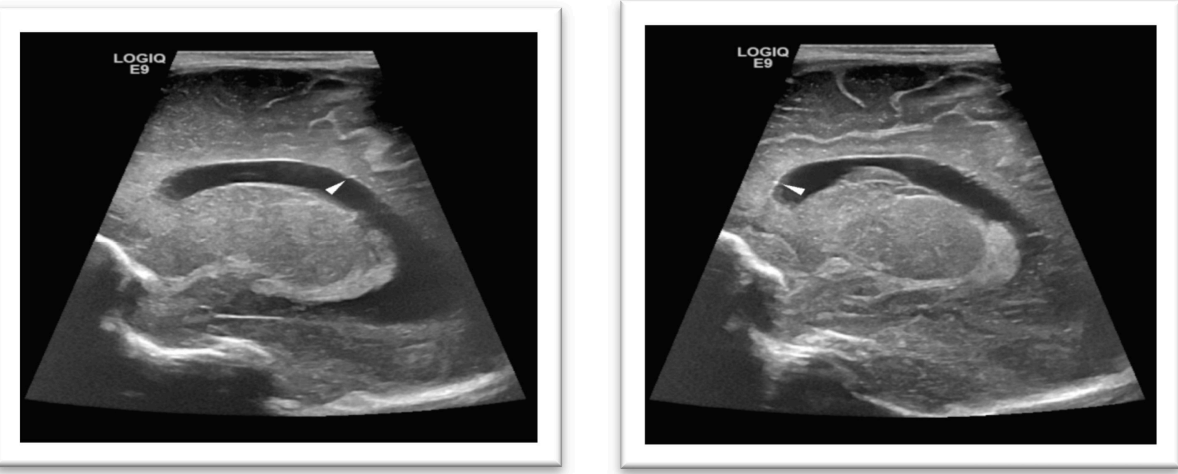
Figura 3: Neurossonografia transfontanelar mostrando cistos subependimários bilaterais.

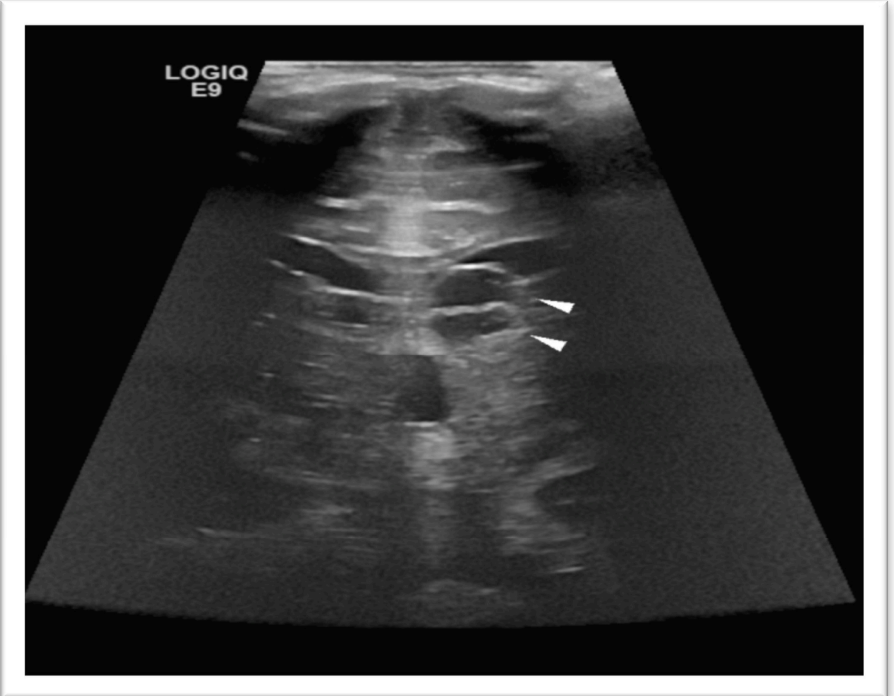

Figura 4: Ressonância Magnética cerebral com ventriculomegalia supratentorial e cistos subependimários.

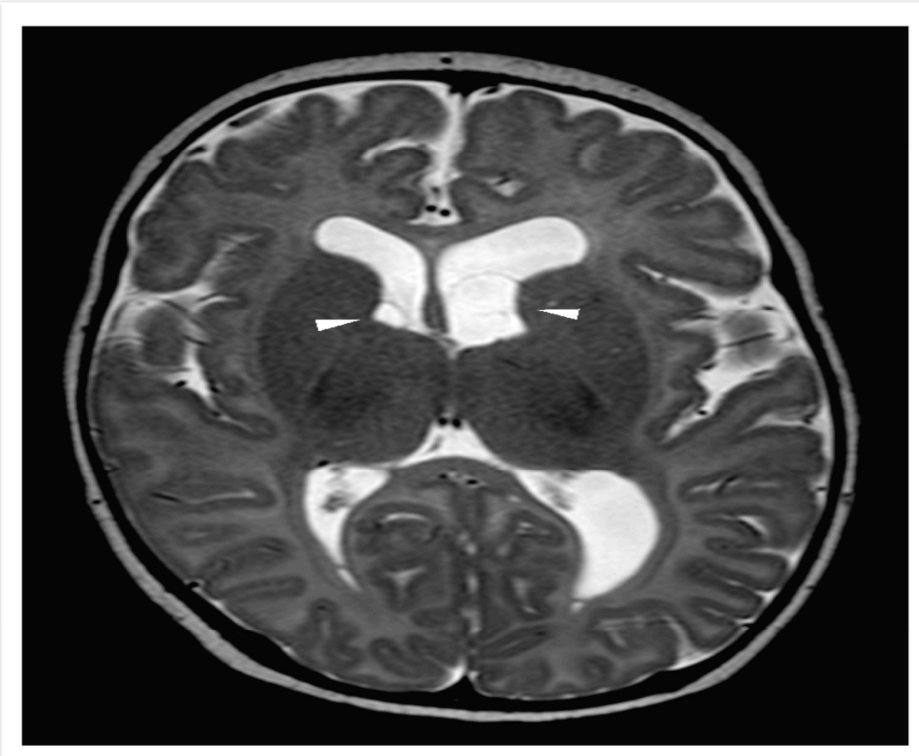




\section{Avaliação dos potenciais fatores preditivos de surdez neurossensorial:}

Considerando todas as 66 crianças infectadas, sintomáticas e assintomáticas, não foi observada associação entre a presença de achados anormais em neuroimagens sugestivos de infecção congênita e ocorrência de surdez neurossensorial relacionada ao CMV. Em relação à presença de alterações laboratoriais, caracterizada pela plaquetopenia e ou aumento nos níveis de YGT, observou-se uma associação com a ocorrência de surdez; entretanto, quando ajustado para presença de sintomas, as alterações de exames laboratoriais não foram fatores de risco independentes associados com a surdez neurossensorial. A presença de sintomas foi o único fator de risco com associação significativa para ocorrência de surdez. Estes dados estão mostrados na Tabela 5 .

Tabela 5: Estimativa do risco relativo (RR) e seu intervalos de confiança para verificar associação entre a presença de alteração de exames laboratoriais, alteração de neuroimagens (NTF e/ou RMc) e sinais clínicos com a ocorrência de surdez neurossensorial.

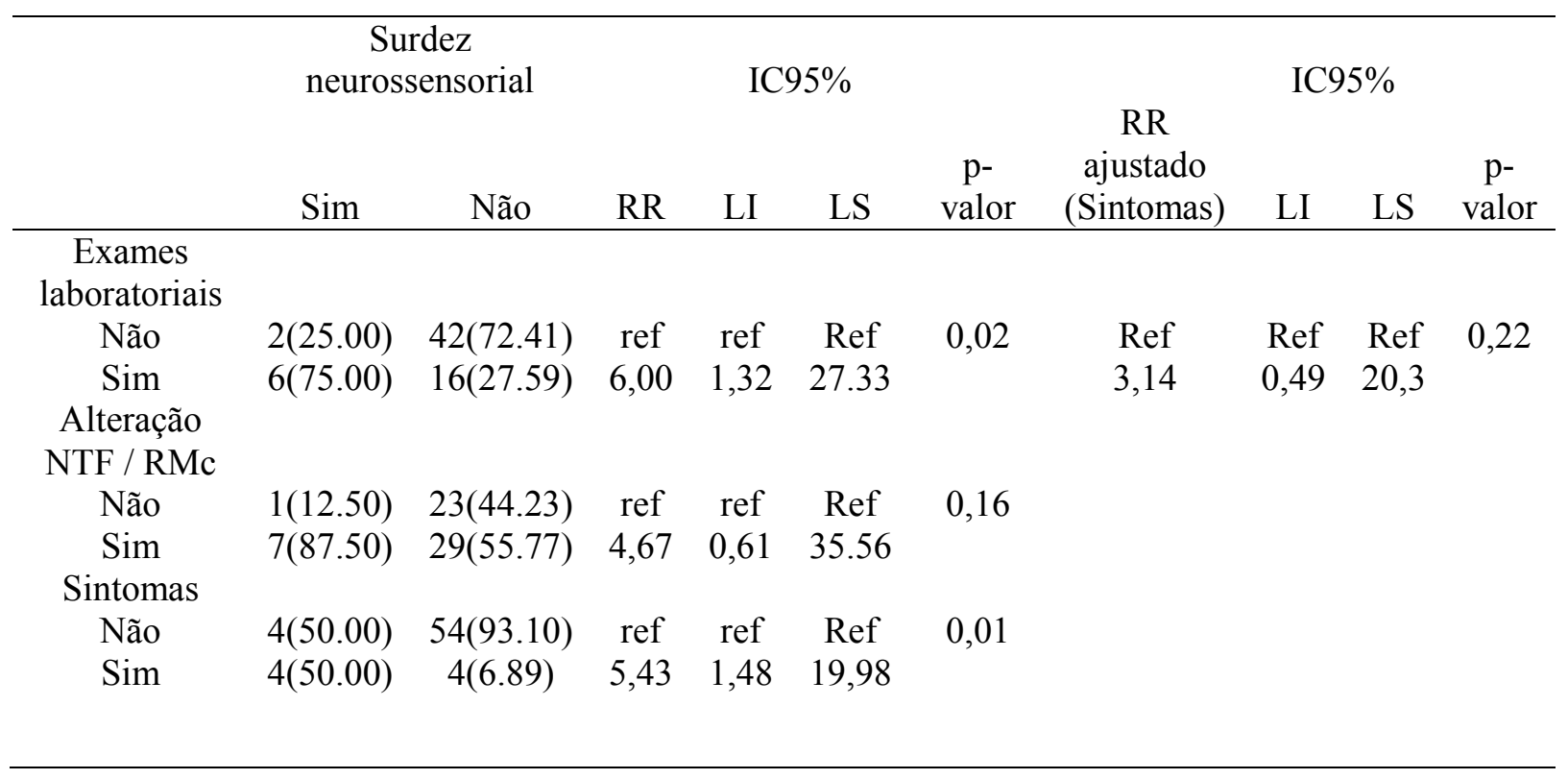

Ainda considerando o total de 66 crianças infectadas, observou-se associação entre a presença de alterações nos exames laboratoriais e a presença de alterações à NTF. O cálculo da razão de risco ajustado para a presença de sintomas não foi realizada considerando que nenhuma criança sintomática apresentou US normal, como mostra a Tabela 6. 
Tabela 6: Razão de risco (RR) e seus intervalos de confiança (95\% IC) para testar associação entre alterações de exames laboratoriais e alterações de neuroimagens (NTF e/ou RMc).

\begin{tabular}{lcccccc}
\hline & \multicolumn{2}{c}{ Alteração NTF / RMc } & \multicolumn{5}{c}{ IC95\% } \\
& Sim & Não & RR & LI & LS & p-valor \\
\hline $\begin{array}{l}\text { Alt. exames } \\
\text { laboratoriais }\end{array}$ & & & & & & \\
$\quad$ Não & $17(50.00)$ & $22(88.00)$ & Ref & ref & Ref & $<0,01$ \\
Sim & $17(50.00)$ & $3(12.00)$ & 1,95 & 1,3 & 2,91 & \\
& & & & & & Teste exato \\
Sintomas & & & & & & de Fisher \\
Não & $26(50.98)$ & $25(49.02)$ & $*$ & $*$ & $*$ & 0,02 \\
Sim & $8(100.00)$ & $0(0.00)$ & $*$ & $*$ & $*$ & \\
\hline
\end{tabular}

Com relação às 53 crianças sem achados clínicos ao nascer ou assintomáticas e que realizaram todas as avaliações, observou-se uma associação entre a presença de alterações em exames laboratoriais e achados anormais em NTF e/ou RMc, em análise univariada, como mostra a Tabela 7.

Tabela 7: Estimativa do risco relativo e seus intervalos de confiança para verificar associação entre alterações de exames laboratoriais e alterações de neuroimagens (NTF e/ou RMc).

\begin{tabular}{lccccccc}
\hline & \multicolumn{2}{c}{ Alterações de NTF / RMc } & & \multicolumn{2}{c}{ IC95\% } & \\
& Sim & Não & & RR & LI & LS & p-valor \\
\hline Alt. exames & & & & & & \\
laboratoriais & & & & & & \\
$\quad$ Não & $20(66.67)$ & $21(91.30)$ & Ref & ref & ref & \\
$\quad$ Sim & $10(33.33)$ & $2(8.70)$ & 1,71 & 1,14 & 2,56 & 0,03 \\
\hline
\end{tabular}

A Tabela 8 mostra que não foi observada associação entre alterações de exames laboratoriais e ocorrência de surdez neurossensorial em 58 crianças assintomáticas. Embora a presença de achados anormais em exames de NTF tenha sido observado em 3 de 4 crianças assintomáticas (75\%) com surdez neurossensorial, não houve associação entre as duas variáveis, como mostra a Tabela 9.

Tabela 8: Estimativa do risco relativo e seus intervalos de confiança para determinar a associação entre alterações de exames laboratoriais e ocorrência de surdez neurosensorial (análise univariada).

\begin{tabular}{lcccccc}
\hline & \multicolumn{2}{c}{ Surdez neurosensorial } & \multicolumn{4}{c}{ IC95\% } \\
& Sim & Não & RR & LI & LS & p-valor \\
\hline Alt. exames & & & & & & \\
laboratoriais & & & & & & \\
$\quad$ Não & $2(50.00)$ & $42(77.77)$ & Ref & ref & Ref & \\
Sim & $2(50.00)$ & $12(22.23)$ & 3,14 & 0,40 & 20,30 & 0,22 \\
\hline
\end{tabular}


Tabela 9: Risco relativo e seu intervalos de confiança para associação entre a presença de alterações de neuroimagens (NTF e/ou RMc) e ocorrência de surdez neurossensorial (análise univariada).

\begin{tabular}{ccccccc}
\hline & \multicolumn{2}{c}{ Surdez neurossensorial } & \multicolumn{4}{c}{ IC95\% } \\
& Sim & Não & RR & LI & LS & p-valor \\
\hline Alteração & & & & & & \\
NTF / RMc & & & & & & \\
Não & $1(25.00)$ & $22(45.84)$ & Ref & ref & Ref & \\
Sim & $3(75.00)$ & $26(54.16)$ & 2,38 & 0,26 & 21,39 & 0,24 \\
\hline
\end{tabular}

\section{Quantificação do DNA do CMV na urina e associação com ocorrência de surdez neurossensorial, alterações de neuroimagens e presença de sinais clínicos ao nascer:}

A média aritmética da carga viral, obtida pela quantificação do DNA do CMV na urina das 66 crianças com infecção congênita sintomática e assintomática foi de 2,57E+06 cópias/ml. As Figuras 5 a 7 mostram as curvas ROC para os valores de corte da carga viral e a ocorrência de surdez, alterações de NTF e presença de sintomas. Os valores de sensibilidade e especificidade para cada ponto de corte da carga viral são mostrados no Anexo 3. As áreas abaixo da curva (AUC) de 0,61, 0,51 e 0,78 mostram o baixo poder discriminatório da carga viral como preditores destas variáveis. Não foi possível a determinação de um valor de corte da carga viral com uma combinação ótima tanto da sensibilidade e especificidade que discrimine as crianças de risco para a ocorrência de surdez, presença de alterações de neurossonografia e ou presença de sinais clínicos ao nascer. 
Figura 5: Curva ROC obtida para as variáveis carga viral e ocorrência de surdez com os indicadores de sensibilidade e especificidade.

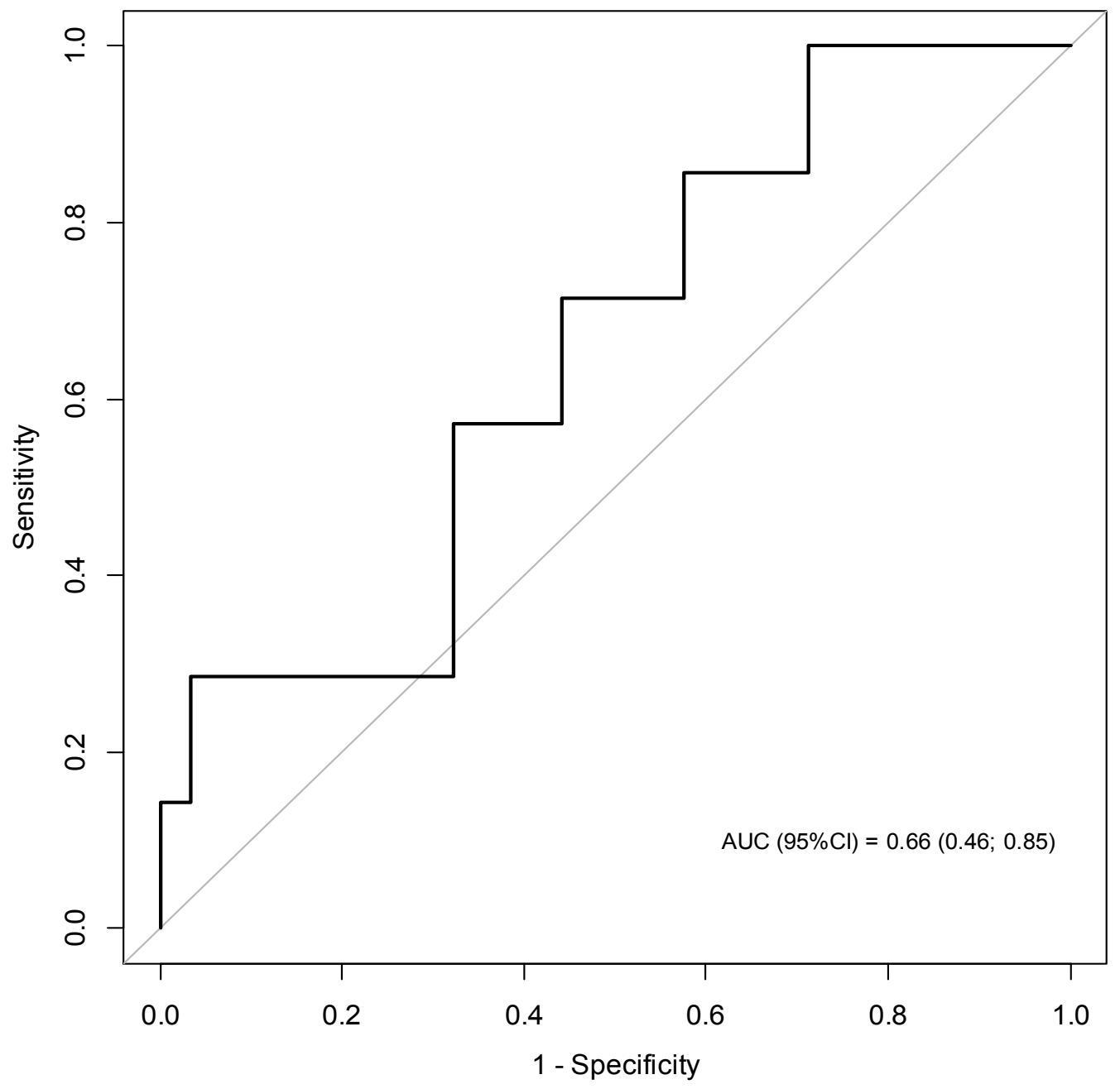


Figura 6: Curva ROC obtida para a carga viral e achados anormais em NTF e/ou RMc com os indicadores de sensibilidade e especificidade.

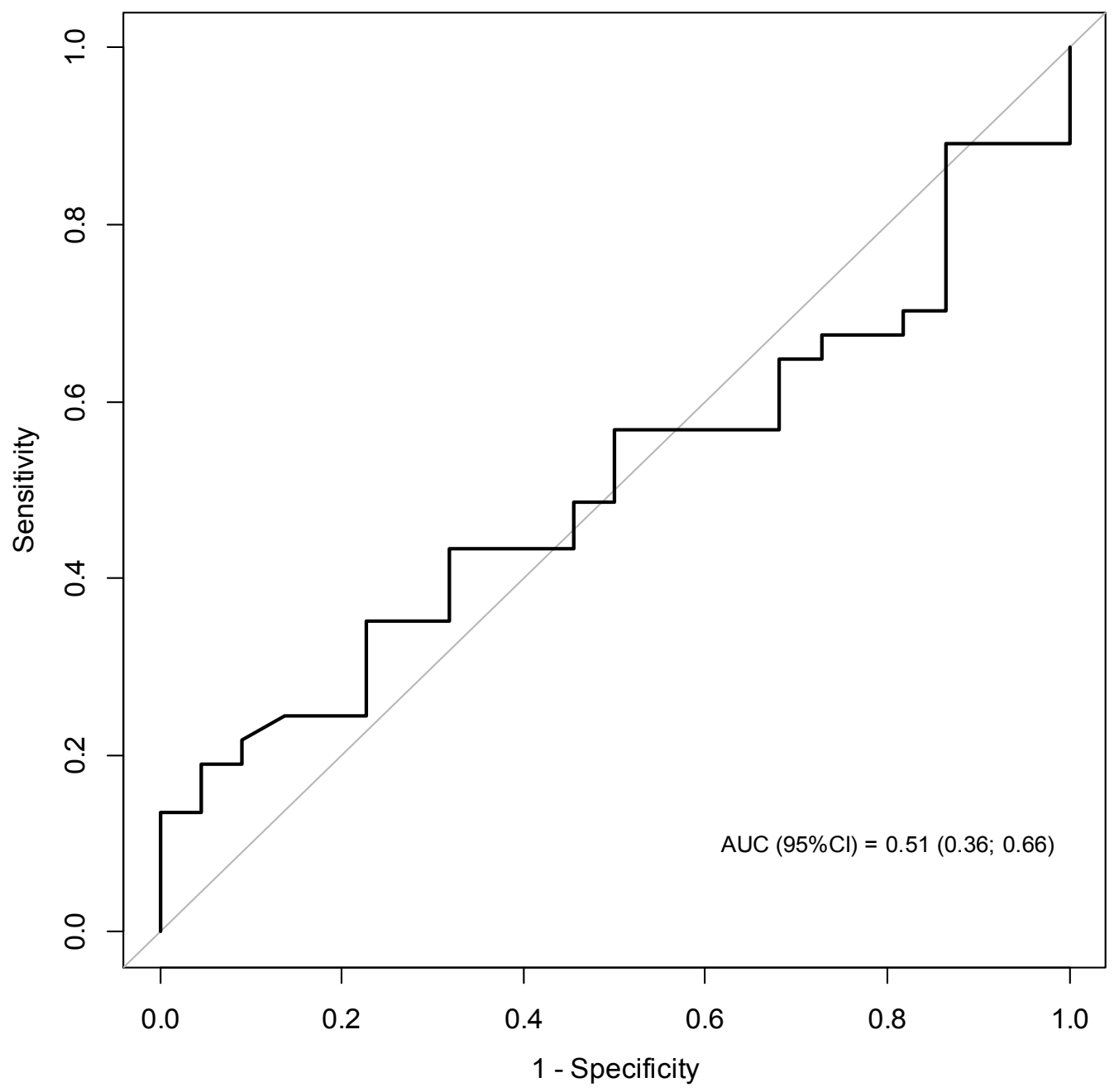


Figura 7: Curva ROC obtida para carga viral e presença sinais clínicos sugestivos de infecção congênita , com os indicadores de sensibilidade e especificidade.

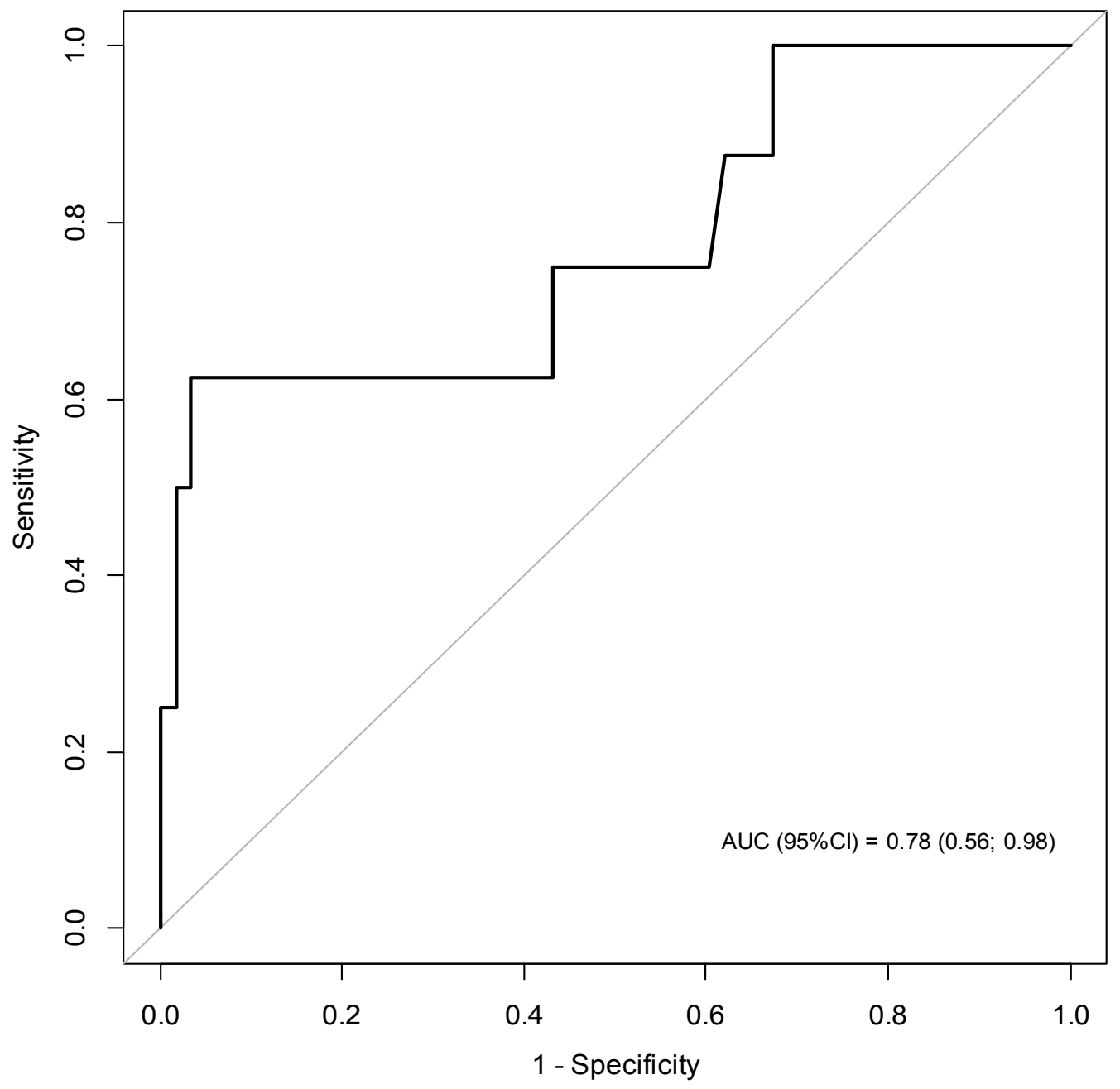




\section{DISCUSSÃO}

Os achados deste estudo mostraram que a proporção de crianças consideradas sintomáticas, ou seja, com alguma apresentação clínica sugestiva de infecção congênita ao nascer, foi similar aos estudos realizados em populações americanas e européias $(18,19,20)$. Entretanto, os achados sugestivos de infecção congênita em avaliações complementares, especialmente aqueles identificados em NTF, foram observados em uma grande proporção $(55,7 \%)$ de crianças que ao nascer não apresentavam nenhuma evidência clínica sugestiva de infecção congênita. Dentre as 29 crianças que apresentaram alterações de NTF e/ou RMc sugestivas de infecção congênita, o achado mais comum foi a vasculopatia lenticuloestriada, acompanhado ou não de cistos subependimários, seguido pela presença de cistos subependimários como único achado, calcificação única ou periventriculares com ou sem áreas de gliose e a ventriculomegalia. Apenas a presença de sintomas clínicos ao nascer foi preditivo para a ocorrência de surdez neurossensorial. Achados de NTF e/ou RMc foram observados em 3 de 4 crianças assintomáticas (75\%) com surdez neurossensorial; entretanto, não foi observada associação com a ocorrência de surdez. A presença de plaquetopenia e/ou níveis altos de gama glutamil transferase (rGT) foi associado com a presença de achados anormais em NTF e/ou RMc em uma análise univariada. O poder discriminatório pela determinação do ponto de corte do valor da carga do DNA do CMV foi avaliada pela curva ROC e não houve associação entre a carga viral e a ocorrência de surdez e/ou achados anormais de NTF e/ou RMc.

Estes resultados geram questionamentos sobre a classificação de infecção congênita "sintomática" e "assintomática" por CMV e contribuem para as evidências da necessidade da realização de uma triagem neonatal sistemática, em larga escala, desta infecção. Embora a taxa de 85 a 90\% de infecção assintomática tenha sido demonstrada em diferentes estudos prévios epidemiológicos $(19,20,29)$, os resultados deste estudo mostraram que muitas destas crianças apresentaram uma infecção "subclínica", com indicação para tratamento antiviral e com potencial para gerar anormalidades futuras.

Observamos que, dentre as crianças que nasceram com alguma manifestação clínica, a plaquetopenia com ou sem petéquias foi mais frequentemente observada, seguida de alterações de enzimas hepáticas, especialmente rGT e da hepatoesplenomegalia. Esses achados são similares aos observados em outros estudos clínicos sobre a doença congênita por CMV, que mostram como anormalidades mais comumente encontradas a hepatoesplenomegalia com ou sem colestase e a presença de petéquias, geralmente presentes em $75 \%$ dos pacientes (57). 
As anormalidades de NTF e/ou RMc sugestivas da doença congênita foram observadas em 87,5\% das crianças sintomáticas e em 55,7\% daquelas consideradas assintomáticas. Dentre as sintomáticas, os achados mais comuns forma as calcificações cerebrais, ventriculomegalia com ou sem cistos subependimários, polimicrogiria, áreas de gliose, a exemplo do que já foi relatado na literatura (29). Por outro lado, dentre as crianças infectadas aparentemente assintomáticas ao nascer, a VLE com ou sem cistos subependimários periventriculares foram os achados mais frequentes. Ao contrário dos sintomáticos, as calcificações cerebrais e a ventriculomegalia foram achados menos frequentes.

A VLE tem sido relatada em 0,4 a 5,8\% dos recém-nascidos que foram submetidos a NTF durante o período neonatal $(58,59)$ e pode estar associada à prematuridade, hemorragia periventricular, doenças metabólicas e infecções congênitas. A presença de VLE sugere que um insulto cerebral possa ter ocorrido antes ou após o nascimento. É provável que seja um marcador não específico de dano cerebral peri e/ou neonatal. (60). Apesar de ter sido inicialmente descrita como achado concomitante de calcificações na US de crânio de RNs com infecções congênitas, a incidência da LSV é muito variável (60). Atualmente observa-se uma tendência crescente de relato destas alterações, que pode refletir apenas o aprimoramento técnico e o crescimento do conhecimento de profissionais que realizam estes exames, que ficam mais atentos a estes achados (60) Assim, a tecnologia pode ter favorecido a identificação desta alteração, mas pode haver um aumento na frequência de fatores de risco que contribuem para a ocorrência da VLE.

Amir et al., 2011 avaliaram 50 crianças com infecção congênita por CMV e encontraram as imagens características de VLE em 54,3\% delas, sendo o único achado em 18/50 (36\%) destas crianças. A ampla variação na definição de VLE e seu reconhecimento na US de crânio resultam em divergências entre observações sobre sua ocorrência e relação com diferentes eventos patológicos antes e após o nascimento. (60) Desta forma, ainda é necessário que o diagnóstico de VLE por meio de NTF seja melhor definido, o que melhoraria não só a confiabilidade do diagnóstico, mas a compreensão de sua patogênese e impacto clinico a longo prazo.

Os cistos subependimários periventriculares têm sido relacionados com mais que 40 patologias, sendo mais comumente associadas às doenças metabólicas, infecções congênitas e alterações cromossômicas $(61,62)$. A sua descrição tem aumentado com a expansão da realização rotineira da US em fetos e recém-nascidos e uma incidência de $0,5 \%$ foi relatada em crianças saudáveis, sem nenhuma patologia predisponente (63). 
Cevey-Macherel et al., seguiram prospectivamente crianças com este achado e mostraram que o desenvolvimento neuropsicomotor foi normal em crianças que não tinham nenhuma patologia associada. Os mesmos autores mostraram que 8/43 (19\%) das crianças eram infectadas congenitamente por CMV, sendo 4 assintomáticas ao nascer (63).

Estudos prévios mostram uma boa correlação entre achados anormais em US cerebral e prognóstico do neurodesenvolvimento de crianças com infecção congênita sintomática por CMV (32). Entretanto, os dados ainda são inconsistentes em relação a recém-nascidos assintomáticos. Noyola et al (30) mostraram que achados de neuroimagem foram os indicadores mais sensíveis de atraso mental (sensibilidade de 100\%); (IC95\%: 82.3- 100) e deficiência motora (sensibilidade de 100\%); (IC 95\%: 78,2-100). Valores preditivos similares foram observados por Boppana et al. (11).

A realização da RMc em nosso estudo foi importante para complementar as alterações observadas nas NTFs identificando achados patológicos adicionais, tais como as anormalidades da substância branca. De acordo com estudos recentes (64), a realização de RMc nos pacientes com infecção congênita por CMV permitiria o diagnóstico precoce de alterações de migração neuronal, contribuindo no prognóstico destas crianças. Entretanto, observamos em nosso estudo que a NTF realizada por um profissional experiente mostrou-se uma ferramenta de avaliação bastante útil na identificação de acometimento neurológico, especialmente naquelas assintomáticas.

A detecção de anormalidades de SNC em crianças com CMV congênito é importante não somente na definição do prognóstico mas também na indicação do tratamento antiviral específico (11). Na prática pediátrica, muitos casos de atraso do desenvolvimento neuropsicomotor, identificadas tardiamente em crianças na idade pré-escolar ou escolar, podem ser secundárias a eventos ocorridos no período intrauterino. A infecção congênita por CMV não identificada ao nascimento, pode ser uma destas causas, pela ausência de manifestações clínicas, mas presentes com o auxílio de uma avaliação complementar, como a NTF.

Neste estudo, os achados anormais em NTF ao nascer foram muito frequentes nas crianças e se estas alterações forem consideradas, a proporção de 12,1\% de sintomáticos aumentaria para 54,5\%. Além disso, tais achados podem ser preditores de anormalidades em crianças com infecção congênita por $\mathrm{CMV}$, especialmente naquelas assintomáticas. Os benefícios da previsão de potencias preditores do risco para anormalidades tardias do neurodesenvolvimento incluem a oportunidade de monitorização adequada e reabilitação com intervenção precoce, bem como a indicação de tratamentos antivirais. 
Com relação à surdez neurossensorial, já é bem documentado que a infecção congênita por CMV contribui significativamente para a perda auditiva pré-lingual em crianças $(27,28)$. A surdez neurossensorial identificada ao nascer, foi observada em 10,6\% das crianças infectadas, taxa similar ao observado em estudo anterior realizado por Yamamoto et al., 2012, nesta mesma população. Destas crianças, 4 eram assintomáticas ao nascer e apresentaram perda auditiva unilateral profunda e 4 eram sintomáticas ao nascer, com surdez profunda bilateral. Desta maneira, a surdez neurossensorial relacionada ao CMV foi observada em $6,9 \%$ das assintomáticas e em $50 \%$ das sintomáticas. Estudos anteriores têm mostrado que $22 \%$ - 65\% das crianças sintomáticas e 6\% - 23\% das assintomáticas apresentam perda auditiva secundária a infecção congênita por $\operatorname{CMV}(27,28)$.

Diferentemente do estudo de Amir et al, que apresentaram evidências de que as alterações em neuroimagens, como a presença de vasculopatia lenticuloestriada, são potenciais preditores de surdez neurossensorial em crianças com infecção congênita, neste estudo, as crianças infectadas com presença de alterações em NTF não apresentaram maior risco de ocorrência de surdez neurossensorial. Os resultados deste estudo e o realizado por Rivera et al., 2002, sugerem que os mecanismos patogênicos que contribuem para o desenvolvimento da surdez neurossensorial em crianças com infecção congênita por CMV, sintomáticas e assintomáticas, podem ser diferentes daqueles responsáveis pelo déficit cognitivo e motor.

Com relação à carga viral do CMV na urina, não foi possível determinar um ponto de corte com ótima sensibilidade e especificidade que discrimine as crianças com maior risco de desenvolver a surdez neurosensorial. Ao contrário do observado por Rivera et al., 2002, que mostraram uma associação significativa entre a carga viral na urina e a proporção de crianças que desenvolveram surdez neurosensorial, no presente estudo esta associação não foi observada. Noyola et al., mostraram que uma proporção significativa de crianças que excretavam o CMV por mais de 4 anos desenvolveram a surdez neurossensorial quando comparado às crianças que excretaram o vírus por mais de 4 anos (38). Os autores sugerem que a resposta imunológica do hospedeiro seria responsável pelo clareamento viral e que a exacerbação desta resposta poderia ter um papel na patogênese da perda auditiva relacionada ao CMV, especialmente a progressiva e de início tardio (38).

Uma vez que é difícil prever quais as crianças com infecção congênita por CMV irão desenvolver perda auditiva e entre quais delas esta perda continuará a deteriorar-se, todas as crianças com infecção congênita por CMV precisam ser identificadas precocemente com monitorização auditiva periódica. Os preditores independentes da surdez neurossensorial 
relacionada ao CMV em crianças assintomáticas e sintomáticas ainda não são conhecidos e neste estudo, não foi possível determinar fatores independentemente preditivos de ocorrência de surdez neurossensorial, embora os achados de NTF podem ser potenciais fatores preditivos de anormalidades tardias em crianças assintomáticas.

No presente estudo, todas as crianças infectadas por CMV (sintomáticas e assintomáticas) estão sendo acompanhadas, com avaliação do crescimento e desenvolvimento, acuidade auditiva e visual. Considerando que até o momento não são disponíveis vacinas para prevenção eficaz da infecção congênita por CMV ou de tratamento materno que definitivamente modifique a sua evolução, será fundamental que crianças portadoras de infecção congênita sejam identificadas precocemente, especialmente as assintomáticas. A triagem neonatal da infecção congênita por CMV possibilitaria um real conhecimento do impacto desta infecção em nosso meio, definindo benefícios do tratamento quando indicado e identificando crianças com potencial de sequelas auditivas e neurológicas. Adicionalmente, uma grande proporção de crianças infectadas com ou sem achados anormais poderia ser identificada por meio desta triagem, considerando que a maioria não tem achados clínicos ao nascer. 


\section{CONCLUSÕES}

1. Os achados sugestivos de infecção congênita em NTF em crianças consideradas assintomáticas ao nascer são freqüentes. Considerando estes achados, a proporção de crianças com achados sugestivos de infecção congênita sintomática, aumentaria de 12,1\% para 54,5\%. 2. Embora não tenha sido possível determinar fatores independentemente preditivos de ocorrência de surdez neurossensorial, os achados de NTF podem ser potenciais fatores preditivos de anormalidades tardias em crianças assintomáticas. A carga viral na urina não discrimina as crianças de risco para a ocorrência de surdez, presença de alterações de NTF e/ou presença de sinais clínicos ao nascer, não sendo portanto um marcador preditor destas anormalidades.

3. A prevalência da surdez neurossensorial relacionada ao CMV foi similar aos estudos prévios, mostrando que a infecção congênita por este vírus é uma importante causa de surdez não hereditária na infância.

4. O poder discriminatório pela determinação do ponto de corte do valor da carga do DNA do CMV avaliada pela área abaixo da curva ROC (AUC) mostrou que não houve associação entre a carga viral e a ocorrência de surdez e/ou achados anormais de NTF e/ou RMc. 
7 Referências 


\section{REFERÊNCIAS ${ }^{1}$}

1. Ho M. Epidemiology of cytomegalovirus infections. Rev Infect Dis. 1990;2 Suppl 7:S701-10.

2. Chee MS, Bankier AT, Beck S, Bohni R, Brown CM, Cerny R, et al. Analysis of the protein-coding content of the sequence of human cytomegalovirus strain AD169. Curr Top Microbiol Immunol. 1990;154:125-69.

3. Mocarski ES Jr. Cytomegaloviruses and their replication. In: Fields BN, Knipe PM, editors. Fields virology. 3rd ed. New York: Raven Press; 1996. p. 2447-92.

4. Alford CA, Stagno S, Pass RF, Britt WJ. Congenital and perinatal cytomegalovirus infections. Rev Infect Dis. 1990;12 Suppl 7:S745-53.

5. Pannuti CS, Vilas-Boas LS, Angelo MJ, Carvalho RP, Segre CM. Congenital cytomegalovirus infection. Occurrence in two socioeconomically distinct populations of a developing country. Rev Inst Med Trop Sao Paulo. 1985;27(2):105-7.

6. Stagno S, Pass RF, Dworsky ME, Alford CA. Congenital and perinatal cytomegalovirus infections. Semin Perinatol. 1983;7(1):31-42.

7. Taylor-Wiedeman J, Sissons JG, Borysiewicz LK, Sinclair JH. Monocytes are a major site of persistence of human cytomegalovirus in peripheral blood mononuclear cells. J Gen Virol. 1991;72(Pt 9):2059-64.

8. Adler SP. Cytomegalovirus and child day care: risk factors for maternal infection. Pediatr Infect Dis J. 1991;10(8):590-4.

9. Britt WJ, Alford CA. Cytomegalovirus. In: Fields BN, Knipe DM, Howley PM, editors. Virology. 3rd ed. Philadelphia: Raven Press; 1996. p. 2493-523.

10. Ahlfors K, Ivarsson SA, Harris S. Report on a long-term study of maternal and congenital cytomegalovirus infection in Sweden. Review of prospective studies available in the literature. Scand J Infect Dis. 1999;31(5):443-57.

\footnotetext{
${ }^{1}$ De acordo com as Normas Vancouver ( Universidade de São Paulo - Sistema Integrado de Bibliotecas Bibliotecas - Diretrizes para apresentação de dissertações e teses da USP, $\mathbf{3}^{\mathbf{a}}$ edição, Revisada, Ampliada e Modificada, 2016
} 
11. Boppana SB, Fowler KB, Britt WJ, Stagno S, Pass RF. Symptomatic congenital cytomegalovirus infection in infants born to mothers with preexisting immunity to cytomegalovirus. Pediatrics. 1999;104(1 Pt 1):55-60.

12. Rahav G, Gabbay R, Ornoy A, Shechtman S, Arnon J, Diav-Citrin O. Primary versus nonprimary cytomegalovirus infection during pregnancy, Israel. Emerg Infect Dis. 2007;13(11):1791-3.

13. Stagno S, Pass RF, Dworsky ME, Alford CA Jr. Maternal cytomegalovirus infection and perinatal transmission. Clin Obstet Gynecol. 1982;25(3):563-76.

14. Brown HL, Abernathy MP. Cytomegalovirus infection. Semin Perinatol. 1998;22(4):260-6.

15. Kenneson A, Cannon MJ. Review and meta-analysis of the epidemiology of congenital cytomegalovirus (CMV) infection. Rev Med Virol. 2007;17(4):253-76.

16. Yamamoto AY, Castellucci RA, Aragon DC, Mussi-Pinhata MM. Early high CMV seroprevalence in pregnant women from a population with a high rate of congenital infection. Epidemiol Infect. 2013;141(10):2187-91.

17. Mussi-Pinhata MM, Yamamoto AY, MouraBrito RM, de Lima Isaac M, de Carvalho e Oliveira PF, Boppana S, Britt WJ. Birth prevalence and natural history of congenital cytomegalovirus infection in a highly seroimmune population. Clin Infect Dis. 2009;15;49(4):522-8.

18. Dollard SC, Grosse SD, Ross DS. New estimates of the prevalence of neurological and sensory sequelae and mortality associated with congenital cytomegalovirus infection. Rev Med Virol. 2007;17(5):355-63.

19. Ross SA, Boppana SB. Congenital cytomegalovirus infection: outcome and diagnosis. Semin Pediatr Infect Dis. 2005;16(1):44-9.

20. Manicklal S, Emery VC, Lazzarotto T, Boppana SB, Gupta RK. The "silent" global burden of congenital cytomegalovirus. Clin Microbiol Rev. 2013;26(1):86-102.

21. Yamamoto AY, Mussi-Pinhata MM, Lima IM, Amaral FR, Carvalheiro CG, Aragon DC, et al. Congenital cytomegalovirus infection as a cause of sensorineural hearing loss in a highly immune population. Pediatr Infect Dis J. 2011;30(12):1043-6. 
22. Boppana SB, Fowler KB, Pass RF, Rivera LB, Bradford RD, Lakeman FD, et al. Congenital cytomegalovirus infection: association between virus burden in infancy and hearing loss. J Pediatr. 2005;146(6):817-23.

23. Bradford RD, Cloud G, Lakeman AD, Boppana S, Kimberlin DW, Jacobs R, et al. Detection of cytomegalovirus (CMV) DNA by polymerase chain reaction is associated with hearing loss in newborns with symptomatic congenital CMV infection involving the central nervous system. J Infect Dis. 2005;15;191(2):227-33.

24. Cheeran MC, Lokensgard JR, Schleiss MR. Neuropathogenesis of congenital cytomegalovirus infection: disease mechanisms and prospects for intervention. Clin Microbiol Rev. 2009;22(1):99-126.

25. Lanari M, Capretti MG, Lazzarotto T, Gabrielli L, Rizzollo S, Mostert M, et al. Neuroimaging in CMV congenital infected neonates: how and when. Early Hum Dev. 2012;88 Suppl 2:S3-5.

26. Alarcon A, Martinez-Biarge M, Cabañas F, Hernanz A, Quero J, Garcia-Alix A. Clinical, biochemical, and neuroimaging findings predict long-term neurodevelopmental outcome in symptomatic congenital cytomegalovirus infection. $\mathrm{J}$ Pediatr. 2013;163(3):828-34.

27. Fowler KB, Dahle AJ, Boppana SB, Pass RF. Newborn hearing screening: will children with hearing loss caused by congenital cytomegalovirus infection be missed? J Pediatr. 1999;135(1):60-4.

28. Dahle AJ, Fowler KB, Wright JD, Boppana SB, Britt WJ, Pass RF. Longitudinal investigation of hearing disorders in children with congenital cytomegalovirus. J Am Acad Audiol. 2000;11(5):283-90.

29. Boppana SB, Pass RF, Britt WJ, Stagno S, Alford CA. Symptomatic congenital cytomegalovirus infection: neonatal morbidity and mortality. Pediatr Infect Dis J. 1992;11(2):93-9.

30. Noyola DE, Demmler GJ, Nelson CT, Griesser C, Williamson WD, Atkins JT, et al. Early predictors of neurodevelopmental outcome in symptomatic congenital cytomegalovirus infection. J Pediatr. 2001;138(3):325-31.

31. Capretti MG, Lanari M, Tani G, Ancora G, Sciutti R, Marsico C, et al. Role of cerebral ultrasound and magnetic resonance imaging in newborns with congenital cytomegalovirus infection. Brain Dev. 2014;36(3):203-11. 
32. Ancora G, Lanari M, Lazzarotto T, Venturi V, Tridapalli E, Sandri F, et al. Cranial ultrasound scanning and prediction of outcome in newborns with congenital cytomegalovirus infection. J Pediatr. 2007;150(2):157-61.

33. Malinger G, Lev D, Zahalka N, Ben Aroia Z, Watemberg N, Kidron D, et al. Fetal cytomegalovirus infection of the brain: the spectrum of sonographic findings. Am $\mathrm{J}$ Neuroradiol. 2003;24(1):28-32.

34. Van der Knaap MS, Vermeulen G, Barkhof F, Hart AA, Loeber JG, Weel JF, et al. Pattern of white matter abnormalities at MR imaging: use of polymerase chain reaction testing of Guthrie cards to link pattern with congenital cytomegalovirus infection. Radiology. 2004;230(2):529-36.

35. Yamamoto AY, Aquino VH, Figueiredo LT, Mussi-Pinhata MM. [Diagnosis of congenital and perinatal infection by cytomegalovirus using polymerase chain reaction]. Rev Soc Bras Med Trop. 1998;31(1):19-26. Article in Portuguese.

36. Mussi-Pinhata MM, Yamamoto AY. [Congenital and perinatal infections]. J Pediatr. 1999;75 Suppl 1:S15-30. [Article in Portuguese]

37. Ogawa H, Suzutani T, Baba Y, Koyano S, Nozawa N, Ishibashi K, et al. Etiology of severe sensorineural hearing loss in children: independent impact of congenital cytomegalovirus infection and GJB2 mutations. J Infect Dis. 2007;195(6):782-8.

38. Noyola DE, Demmler GJ, Williamson WD, Griesser C, Sellers S, Llorente A, et al. Cytomegalovirus urinary excretion and long term outcome in children with congenital cytomegalovirus infection. Congenital CMV Longitudinal Study Group. Pediatr Infect Dis J. 2000;19(6):505-10.

39. Pass RF. Congenital cytomegalovirus infection and hearing loss. Herpes. 2005;12(2):50-5.

40. Davis LE, Johnsson LG, Kornfeld M. Cytomegalovirus labyrinthitis in an infant: morphological, virological, and immunofluorescent studies. J Neuropathol Exp Neurol. 1981;40(1):9-19.

41. Strauss M. A clinical pathologic study of hearing loss in congenital cytomegalovirus infection. Laryngoscope. 1985;95(8):951-62.

42. Sugiura S, Yoshikawa T, Nishiyama Y, Morishita Y, Sato E, Hattori T, et al. Detection of human cytomegalovirus DNA in perilymph of patients with sensorineural hearing loss using real-time PCR. J Med Virol. 2003;69(1):72-5. 
43. Barkovich AJ, Girard N. Fetal brain infections. Childs Nerv Syst. 2003;19(7-8):501-7.

44. Barkovich AJ, Lindan CE. Congenital cytomegalovirus infection of the brain: imaging analysis and embryologic considerations. AJNR Am J Neuroradiol. 1994;15(4):703-15.

45. Williamson WD, Percy AK, Yow MD, Gerson P, Catlin FI, Koppelman ML, et al. Asymptomatic congenital cytomegalovirus infection. Audiologic, neuroradiologic, and neurodevelopmental abnormalities during the first year. Am J Dis Child. 1990;144(12):1365-8.

46. Haginoya K, Ohura T, Kon K, Yagi T, Sawaishi Y, Ishii KK, et al. Abnormal white matter lesions with sensorineural hearing loss caused by congenital cytomegalovirus infection: retrospective diagnosis by PCR using Guthrie cards. Brain Dev. 2002;24(7):710-4.

47. Amir J, Schwarz M, Levy I, Haimi-Cohen Y, Pardo J. Is lenticulostriated vasculophaty a sign of central nervous system insult in infants with congenital CMV infection? Arch Dis Child. 2011;96(9):846-50.

48. Colebatch AN, Edwards CJ, Østergaard M, van der Heijde D, Balint PV, D'Agostino MA et al. EULAR recommendations for the use of imaging of the joints in the clinical management of rheumatoid arthritis. Ann Rheum Dis. 2013;72(6):804-14.

49. Halwachs-Baumann G. The congenital cytomegalovirus infection: virus-host interaction for defense and transmission. Curr Pharm Biotechnol. 2006;7(4):303-12.

50. Pereira L, Maidji E, McDonagh S, Tabata T. Insights into viral transmission at the uterine-placental interface. Trends Microbiol. 2005;13(4):164-74.

51. La Torre R, Nigro G, Mazzocco M, Best AM, Adler SP. Placental enlargement in women with primary maternal cytomegalovirus infection is associated with fetal and neonatal disease. Clin Infect Dis. 2006;15;43(8):994-1000.

52. Mezzacappa MA. Citomegalovirus. In: Marba STM, Mezzacappa Filho F, editors. Manual de neonatologia - UNICAMP. Rio de Janeiro: Revinter; 1998. p. 252-255

53. Kimberlin DW, Acosta EP, Sánchez PJ, Sood S, Agrawal V, Homans J, et al. Pharmacokinetic and pharmacodynamic assessment of oral valganciclovir in the treatment of symptomatic congenital cytomegalovirus disease. $\mathrm{J}$ Infect Dis. 2008;15;197(6):836-45. 
54. Pickering LK, Baker CJ, Long SS, Kimberlin DW, editors. Red Book: 2012 report of the Committee on Infectious Diseases. Elk Grove Village: American Academy of Pediatrics; 2012. Cytomegalovirus infection; p. 300-5.

55. Blizzard L, Hosmer DW. Parameter estimation and goodness-of-fit in log binomial regression. Biom J. 2006;48(1):5-22.

56. Zweig MH, Campbell G. Receiver-operating characteristic (ROC) plots: a fundamental evaluation tool in clinical medicine. Clin Chem. 1993;39(4):561-77.

57. Yamamoto AY, Figueiredo LT, Mussi-Pinhata MM. [Prevalence and clinical aspects of congenital cytomegalovirus infection]. J Pediatr. 1999;75(1):23-8. [Article in Portuguese]

58. Coley BD, Rusin JA, Boue DR. Importance of hypoxic/ischemic conditions in the development of cerebral lenticulostriate vasculopathy. Pediatr Radiol. 2000;30(12):84655 .

59. Makhoul IR, Eisenstein I, Sujov P, Soudack M, Smolkin T, Tamir A, et al. Neonatal lenticulostriate vasculopathy: further characterisation. Arch Dis Child Fetal Neonatal Ed. 2003;88(5):F410-4.

60. Sisman J, Rosenfeld CR. Lenticulostriate vasculopathy in neonates: Is it a marker of cerebral insult? Critical review of the literature. Early Hum Dev. 2015;91(7):423-6.

61. Cuillier F, Cartault F, Lemaire P, Gruau M, Alessandri JL. [Subependymal pseudocysts in the fetal brain revealing Zellweger syndrome]. J Gynecol Obstet Biol Reprod. 2004;33(4):325-9. [Article in French]

62. Hoffmann GF, Athanassopoulos S, Burlina AB, Duran M, de Klerk JB, Lehnert W, et al. Clinical course, early diagnosis, treatment, and prevention of disease in glutaryl-CoA dehydrogenase deficiency. Neuropediatrics. 1996;27(3):115-23.

63. Cevey-Macherel M, Forcada GM, Bickle GM, Truttmann AC. Neurodevelopment outcome of newborns with cerebral subependymal pseudocysts at 18 and 46 months: a prospective study. Arch Dis Child. 2013;98(7):497-502.

64. Oosterom N, Nijman J, Gunkel J, Wolfs TF, Groenendaal F, Verboon-Maciolek MA, et al. Neuro-imaging findings in infants with congenital cytomegalovirus infection: relation to trimester of infection. Neonatology. 2015;107(4):289-96. 
Anexos 


\section{ANEXOS}

Anexo 1 - Ofícios do Comitê de Ética de autorização da pesquisa no HCFMRP HOSPITAL DAS CLÍNICAS DA FACULDADE DE MEDICINA DE RIBEIRÃO PRETO DA UNIVERSIDADE DE SÄO PAULO

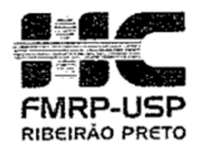

Oficio . $^{\circ} 2191 / 2013$

Ribeirão Preto, 13 de junho de 2013.

$\mathrm{CEP} / \mathrm{MGV}$

PROCESSO HCRP N. 15905/2011

Prezada Pesquisadora,

O Comitê de Ética em Pesquisa, em sua $368^{\mathrm{a}}$ Reunião Ordinária, realizada em 10/06/2013, tomou ciência das respostas das pendências, solicitadas no Parecer CONEP $n^{\circ} 047 / 2013$ datado de 24/04/2013, assim como analisou e aprovou as novas versões dos documentos: TCLE RN e crianças 16-maio-2013 (versão 2.1); TCLE Prê-natal 16-maio-2013 (versão 2.1) e o TCLE para guarda de material biológico no biorrepositório do estudo BraCHS, v. 1.1 de 21 de maio de 2013, referentes à pesquisa: "VACINAS CONTRA O CMV: REINFECÇÃO E VARIAÇÃO ANTIGÊNICA".

O CEP considera que a pesquisadora respondeu adequadamente as pendências solicitadas no Parecer CONEP $n^{\circ}$ 047/2013, no entanto, será encaminhado novamente à CONEP para nova apreciaçāo.

Atenciosamente,

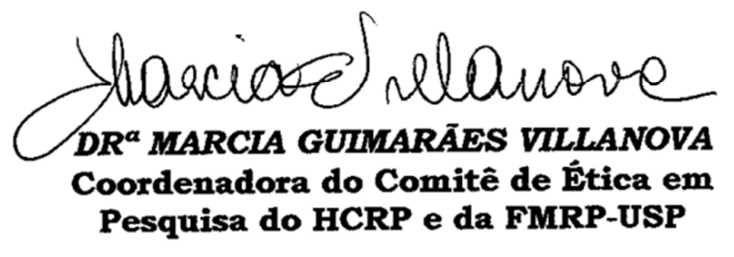

Mustrissima Senhora

PROF ${ }^{2}$. DR ${ }^{2}$. MARISA MÁRCIA MUSSI PINHATA

Departamento de Puericultura e Pediatria 
Anexo 2 - Formulários com os Registros dos pacientes da pesquisa

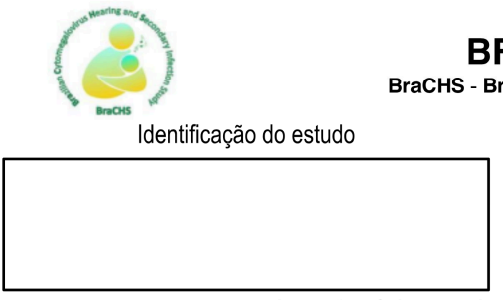

BF101 - Registros Médicos Iniciais

raCHS - Brazilian Cytomegalovirus Hearing and Secondary Infection Study.

Instruções: Coloque a etiqueta de identificação do estudo sem o código de barras na caixa de identificação do estudo

Nome do Médico responsável pela coleta dos dados

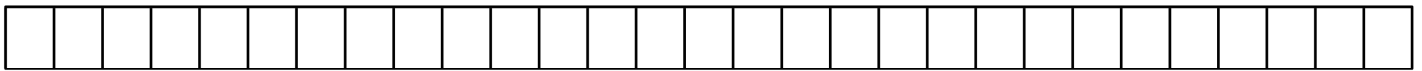

1. Informação do Recém-Nascido (Obtida dos Registros Médicos da Criança): O Sim O Não, justifique:

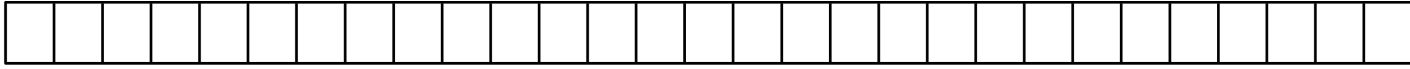

\begin{tabular}{l} 
2. Perímetro Craniano \\
\begin{tabular}{|l|l|}
\hline & \\
\hline
\end{tabular} \\
\hline
\end{tabular}

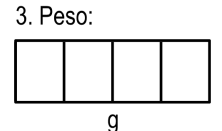

4. Comprimento:

5. Perímetro torácico: (Somente em crianças até 1 ano de vida)

6. Suspeita clínica de infecção congênita $\bigcirc$ Não O Sim

Caso haja anormalidades indicar abaixo:

\begin{tabular}{|c|c|c|c|c|}
\hline Icterícia (Bilirrubina Direta >3mg/dL) & O Sim & O Não & Hepatomegalia & O Sim \\
\hline Esplenomegalia & O Sim & O Não & Pneumonia & O Sim \\
\hline Petéquias & O Sim & O Não & Sufusões hemorrágicas & O Sim \\
\hline Equimoses & O Sim & ○ Não & Hipertonia & O Sim \\
\hline Hipotonia & O Sim & ○ Não & Microcefalia & O Sim \\
\hline Crise convulsiva neonatal & O Sim & O Não & Outras anormalidades neurológicas: & O Sim \\
\hline
\end{tabular}

Especifique:

\begin{tabular}{|l|l|l|l|l|l|l|l|l|l|l|l|l|l|l|l|l|l|l|l|l|l|l|l|l|l|l|l|l|}
\hline & & & & & & & & & & & & & & & & & & & & & & & & & & & \\
\hline & & & & & & & & & & & & & & & & & & & & & & & & & & \\
\hline
\end{tabular}

7. Anormalidades Congênitas - Cabeça/pescoço

O Nenhuma

Canal auditivo esquerdo

Canal auditivo direito

O Estrutura externa da orelha, apêndice pré-auricular esquerdo

Estrutura externa da orelha, apêndice pré-auricular direito

O Fissura do lábio ou palato

O Dismórfico

Outras anormalidades congênitas

\begin{tabular}{|l|l|l|l|l|l|l|l|l|l|l|l|l|l|l|l|l|l|l|l|l|l|l|l|l|l|}
\hline & & & &
\end{tabular}




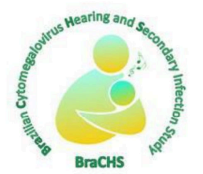

BF101 - Registros Médicos Iniciais

BraCHS - Brazilian Cytomegalovirus Hearing and Secondary Infection Study.

8. Algum sinal de estigma cutâneo ou outros achados compatíveis com alguma síndrome conhecida relacionada com a perda auditiva

O Nenhum O Suspeita, Especifique:

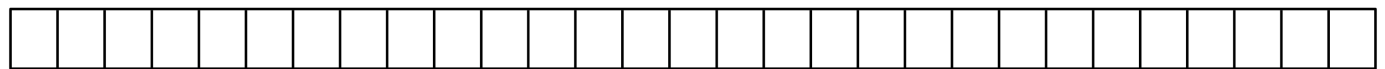

9. Foram observadas outras anormalidades congênitas?

O Não O Sim, especifique:

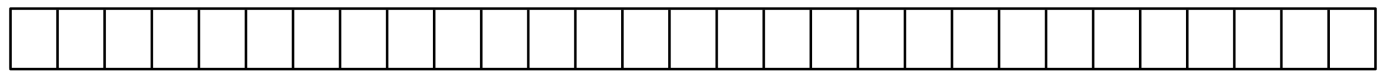

10. Condições clínicas - RN qualquer Idade Gestacional:

Meningite bacteriana

Convulsões

O Síndrome do Desconforto Respiratório

O Sepse confirmada

O Hiperbilirrubinemia, com requisição de transfusão:

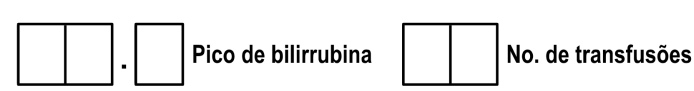

11. Apenas para $R N>36$ semanas ( $\mathrm{Se}<=36$ semanas, marque N/A: Não se aplica)

O N/A O Hipertensão Pulmonar Persistente Neonatal - HPPN O Encefalopatia hipóxico isquêmica (asfixia)

12. Apenas para $R N<32$ semanas (Se<=32 semanas, marque N/A: Não se aplica)

O N/A O Displasia Broncopulmonar / Doença pulmonar crônica

13. Triagem para outras infecções congênitas além do CMV? O Não O Sim, especifique abaixo:

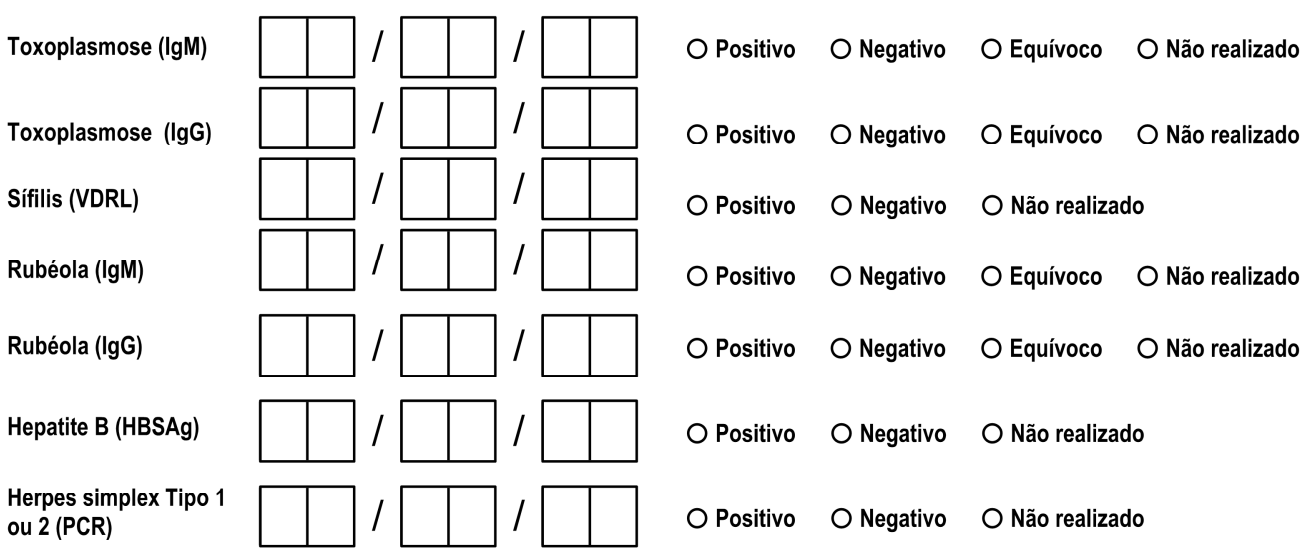

Outros

\begin{tabular}{|l|l|l|l|l|l|l|l|l|l|l|l|l|l|l|l|l|l|l|l|l|l|l|l|l|l|l|l|l|}
\hline & & & & & & & & & & & & & & & & & & & & & & & & & & & \\
\hline
\end{tabular}

Page 2 of 5 


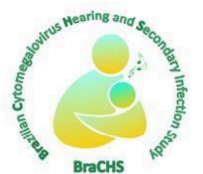

14. Recebeu terapia antiviral para o CMV

Não $\mathrm{O}$ Sim, data do início:
BF101 - Registros Médicos Iniciais

BraCHS - Brazilian Cytomegalovirus Hearing and Secondary Infection Study.

Se SIM, droga antiviral recebida:

O Ganciclovir

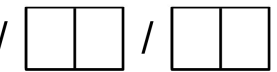

Término terapia antiviral para CMV

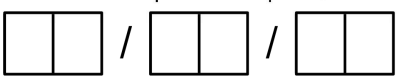

O Valganciclovir

15. Estado da mãe relativo à infeccção pelo HIV (Exposição da Criança ao HIV)

O Exposto ao HIV O Não Infectado pelo HIV O Infectado pelo HIV O Não há Informações no prontuário da mãe

16. A criança recebeu terapia Anti-retroviral para o HIV? O Não O Sim, especique abaixo:

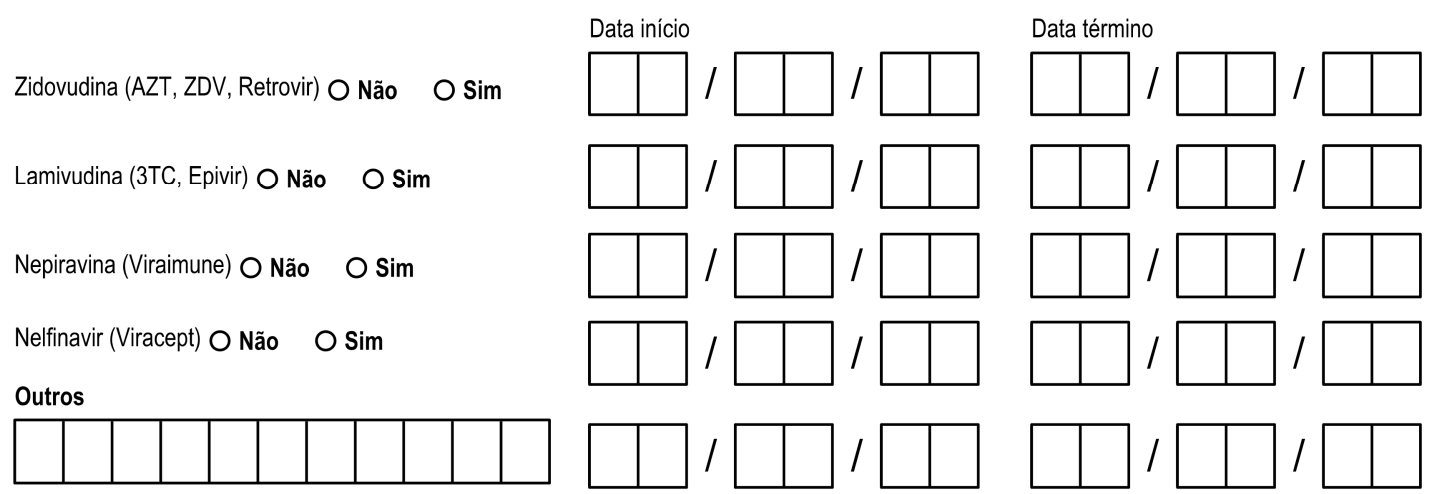

17. Antibióticos: O Não O Sim
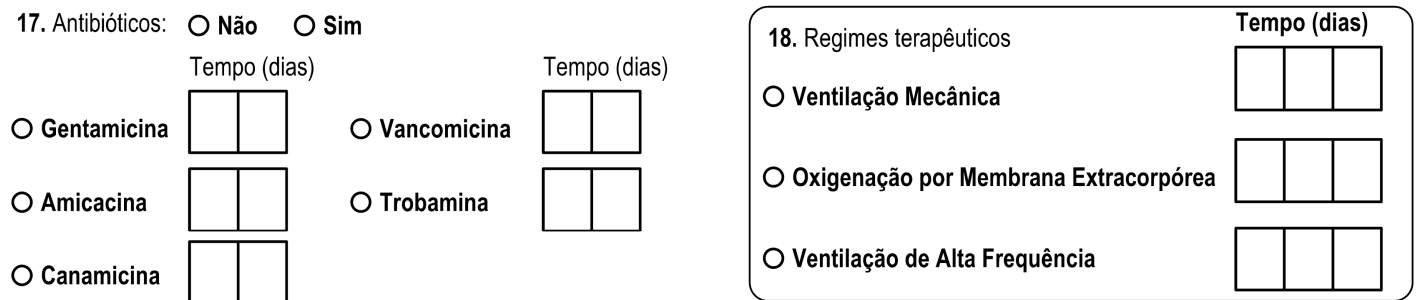

Canamicina

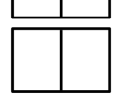

Tempo (dias)

1. Outros antibioticos

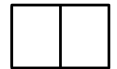

2. Outros antibioticos

Tempo (dias)

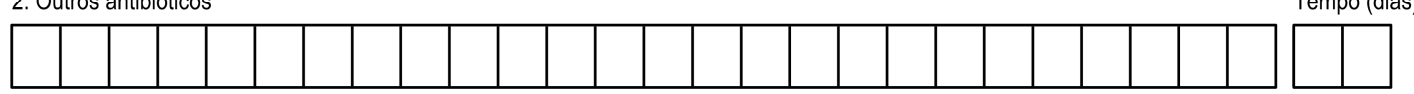

19. Diuréticos de alça: $O$ Não $\bigcirc$ Sim

O Furosemida (Lasix) Tempo (dias)

Outro diurético

Tempo (dias)

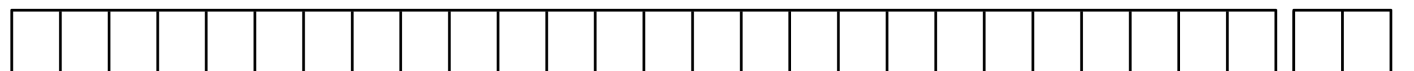

Page 3 of 5 


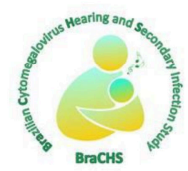

BF101 - Registros Médicos Iniciais

BraCHS - Brazilian Cytomegalovirus Hearing and Secondary Infection Study.

20. A história familiar da criança referente à perda auditiva foi obtida?

O Não

O Não sabe informar

O Não há história de perda auditiva na família

O Sim, Relação com a criança:

\begin{tabular}{|l|l|l|l|l|l|l|l|l|l|l|l|l|l|l|l|l|l|l|l|l|l|l|l|l|l|l|l|}
\hline & & & & & & & & & & & & & & & & & & & & & & & & & & & \\
\hline
\end{tabular}

\section{RESULTADOS LABORATORIAIS}

21. Há algum resultado laboratorial a ser relatado? O Sim O Não

22. Contagem de plaquetas $O$ Não realizado

O Normal
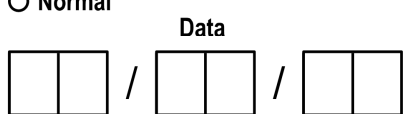

Contagem de plaquetas

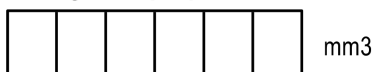

O Alterado

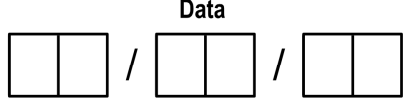

Menor contagem de plaquetas

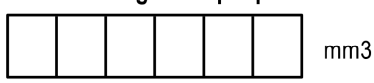

Transfusões de plaquetas $\mathrm{O}$ Nenhuma

Se SIM, número de transfusões:

Data primeira transfusão plaquetas

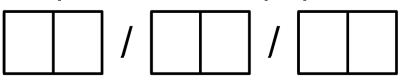

Data última transfusão plaquetas

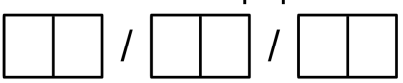

23. Testes de função hepática

O Não realizado

O Normal
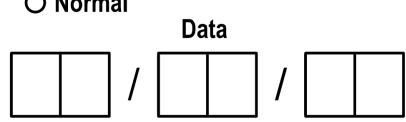

Valor TGO IU/L

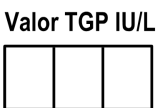

Valor Bilirrubina $\mathrm{mg} / \mathrm{dL} \quad$ Valor Bilirrubina direta $\mathrm{mg} / \mathrm{dL}$

O Alterado

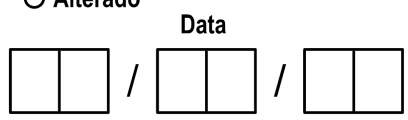

Data
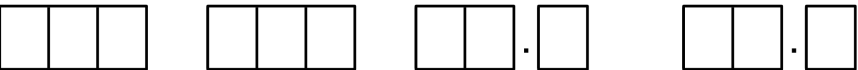

Pico de TGO IU/L

Pico de TGP IU/L
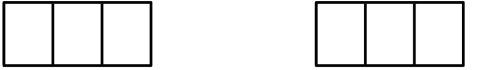

Pico de Bilirrubina $\mathrm{mg} / \mathrm{dL}$

Pico de Bilirrubina direta $\mathrm{mg} / \mathrm{dL}$
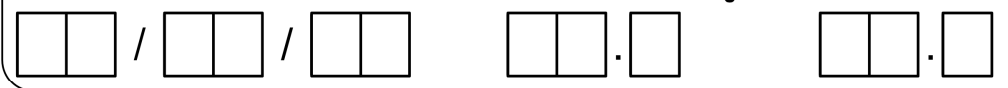

\section{Gama GT O Não realizado}

O Normal

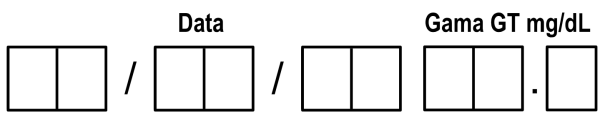

Alterado

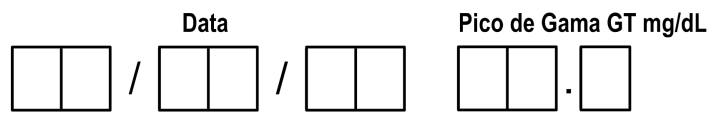




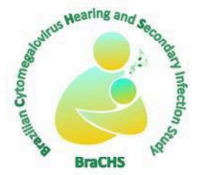

BF101 - Registros Médicos Iniciais

BraCHS - Brazilian Cytomegalovirus Hearing and Secondary Infection Study.

25. Neuroimagem O Nenhum
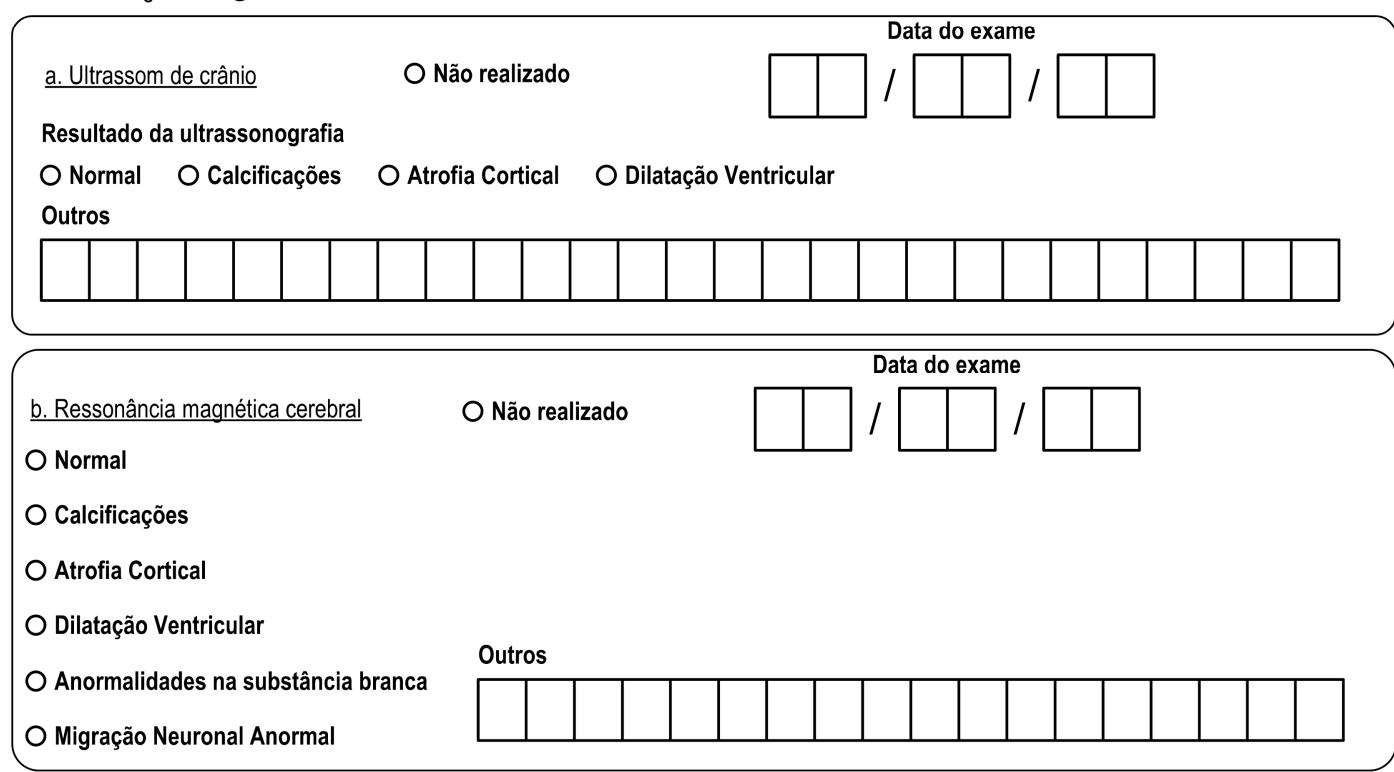

$\begin{aligned} \text { Data do exame } & \text { Dam }\end{aligned}$

c. Tomografia computadorizada do crânio $\quad$ Não realizado

O Normal $\bigcirc$ Calcificações $\bigcirc$ Atrofia Cortical $\bigcirc$ Dilatação Ventricular $\bigcirc$ Anormalidades na substância branca

Outros

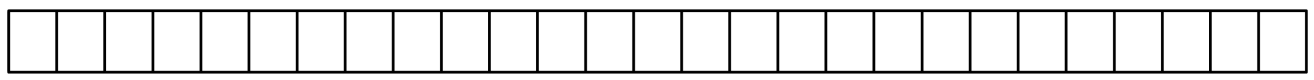

\section{Avaliação ocular $\bigcirc$ Não realizado}

Data do exame

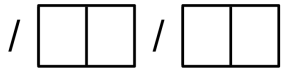

Olho Direito

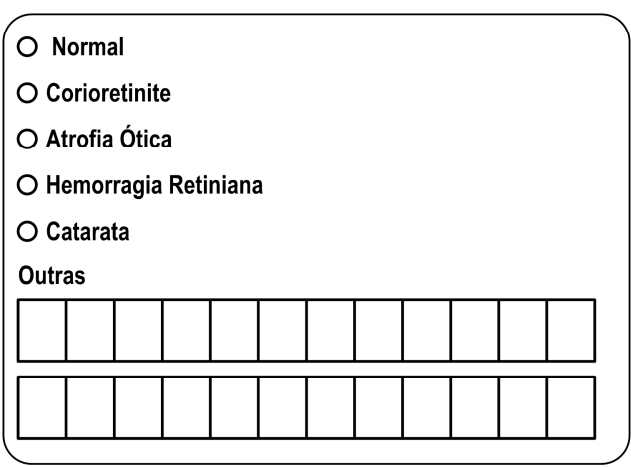

Olho Esquerdo

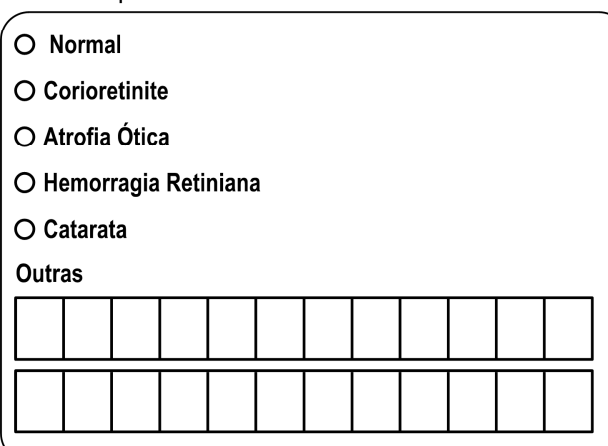

Page 5 of 5 


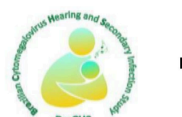

BF102 - Avaliação Física

BraCHS - Brazilian Cytomegalovirus Hearing and Secondary Infection Study.

Identificação do estudo

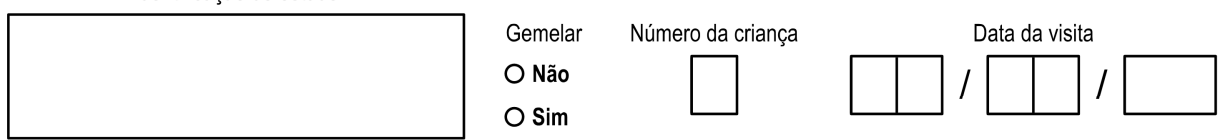

Instruçōes: Coloque a etiqueta de identificação do estudo sem o código de barras na caixa de identificação do estudo

Nome do Médico responsável pela coleta dos dados

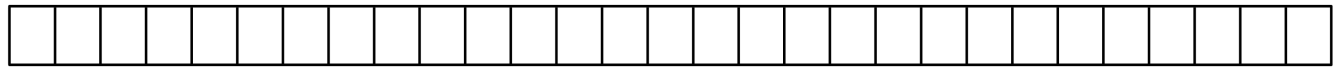

1. Avaliação física no momento da inscrição? Sim, Continue (Questão 2)

Não, justifique. PARE

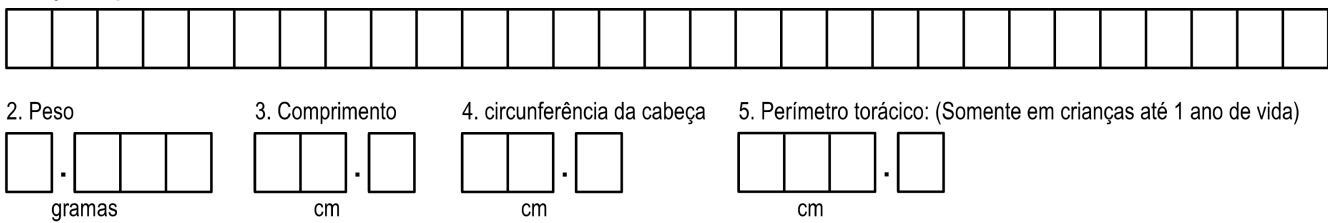

6. Anomalias congênitas observadas

O Nenhuma

O Dimorfismo, Especifique:

O Fenda Labial / Palatina

O Outra, Especifique:
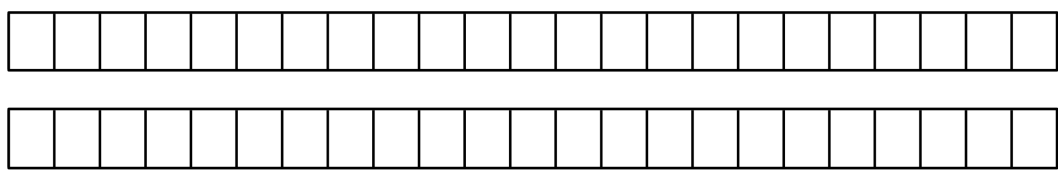

7. Exame de ouvido

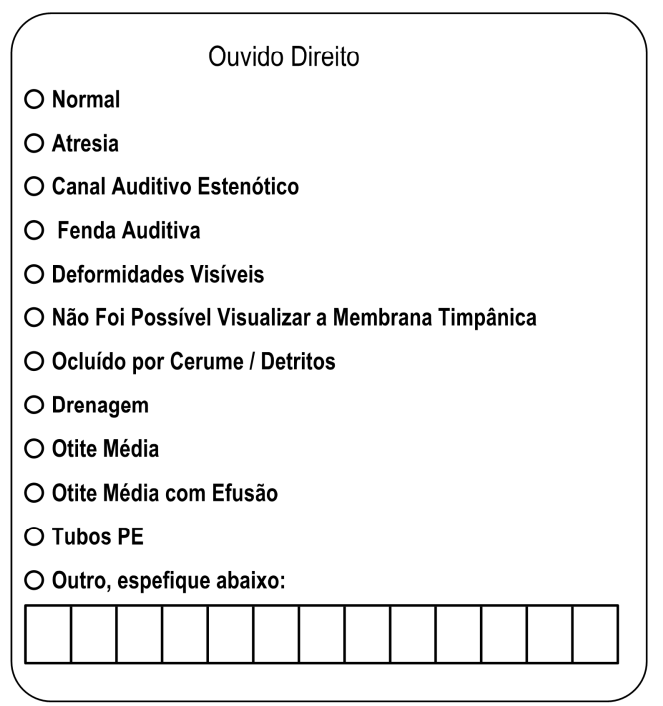

\begin{tabular}{|l|l|}
\hline \multicolumn{4}{|c|}{ Ouvido Esquerdo } \\
O Normal \\
O Atresia \\
O Canal Auditivo Estenótico \\
O Fenda Auditiva \\
O Deformidades Visíveis \\
O Não Foi Possível Visualizar a Membrana Timpânica \\
O Ocluído por Cerume / Detritos \\
O Drenagem \\
O Otite Média \\
O Otite Média com Efusão \\
O Tubos PE \\
O Outro, espefique abaixo: \\
\begin{tabular}{|l|l|l|l|l|l|l|}
\hline & & & & & \\
\hline
\end{tabular}
\end{tabular}

Pace 1 of 2 


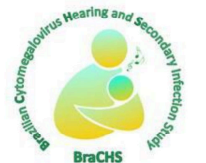

8. Exame ocular:

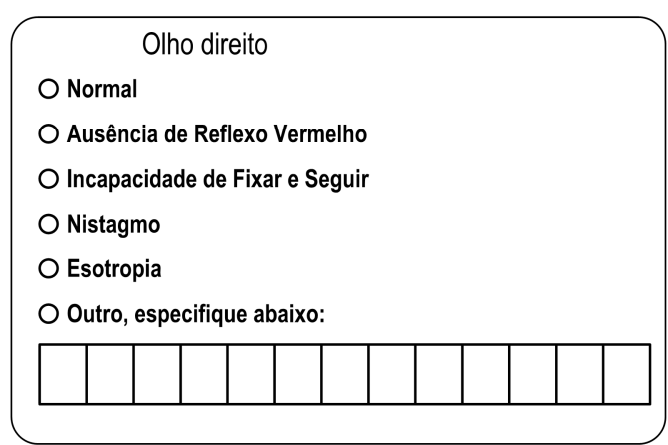

\section{Exame da pele}

O Normal

Manchas Avermelhadas Generalizadas

Manchas Arroxeadas

O Icterícia

\section{BF102 - Avaliação Física}

BraCHS - Brazilian Cytomegalovirus Hearing and Secondary Infection Study.

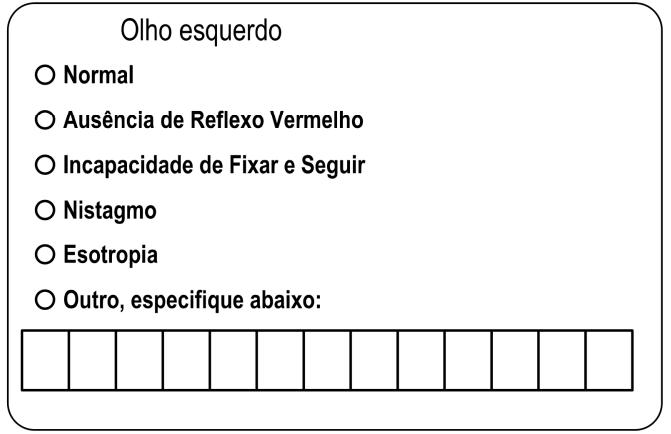

10. Hepatomegalia $\bigcirc$ Sim $\quad$ Não
11. Esplenomegalia $\bigcirc$ Sim $\quad$ O Não

12. Anormalidades Neurológicas

O Nenhuma

Retardo Mental

Hipertonia

O Hipotonia

Tônus Assimétrico

O Força Diminuída

Outras anormalidades neurológicas significativas:

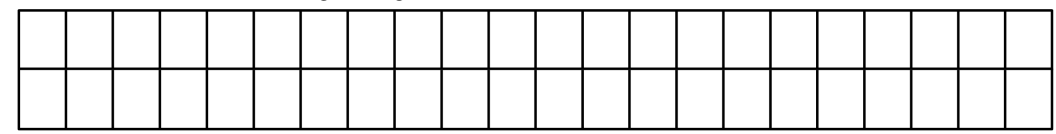

Foram observadas outras comorbidades? O Não O Sim, Especifique abaixo:
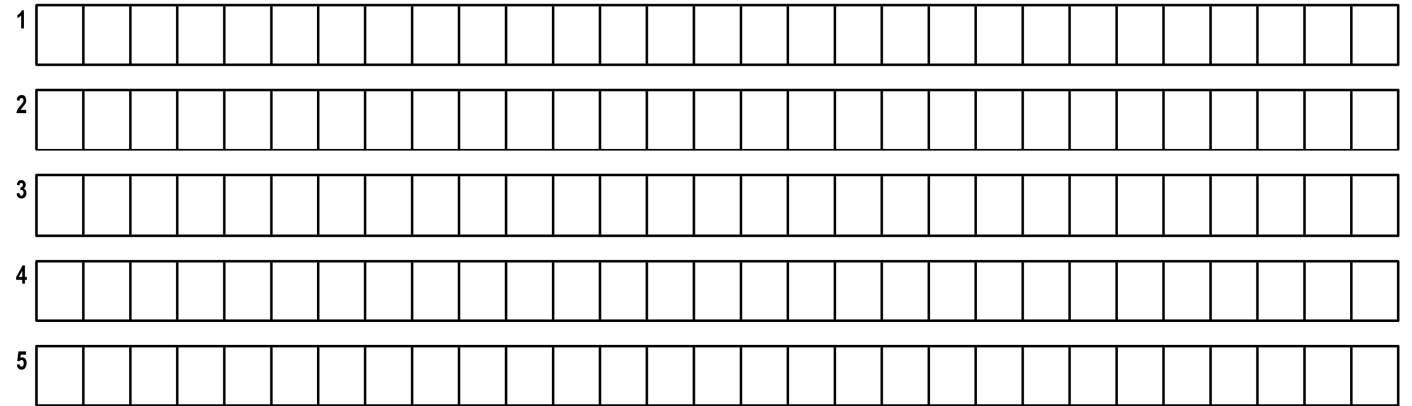

Page 2 of 2 
LB103 - Formulário de Resultados Laboratoriais do CMV - Crianças BraCHS - Brazilian Cytomegalovirus Hearing and Secondary Infection Study.

Identificação do estudo

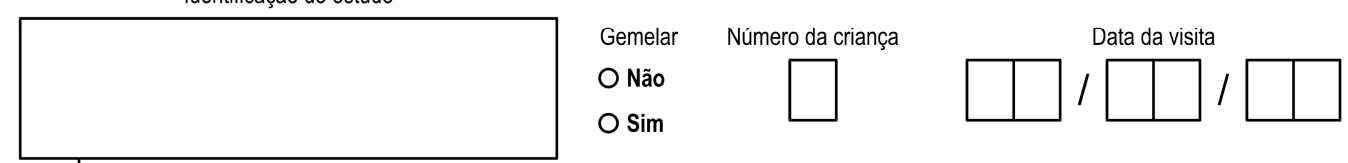

Instruçōes: Coloque a etiqueta de identificação do estudo sem o código de barras na caixa de identificação do estudo

Nome do responsável pelo preenchimento do formulário:

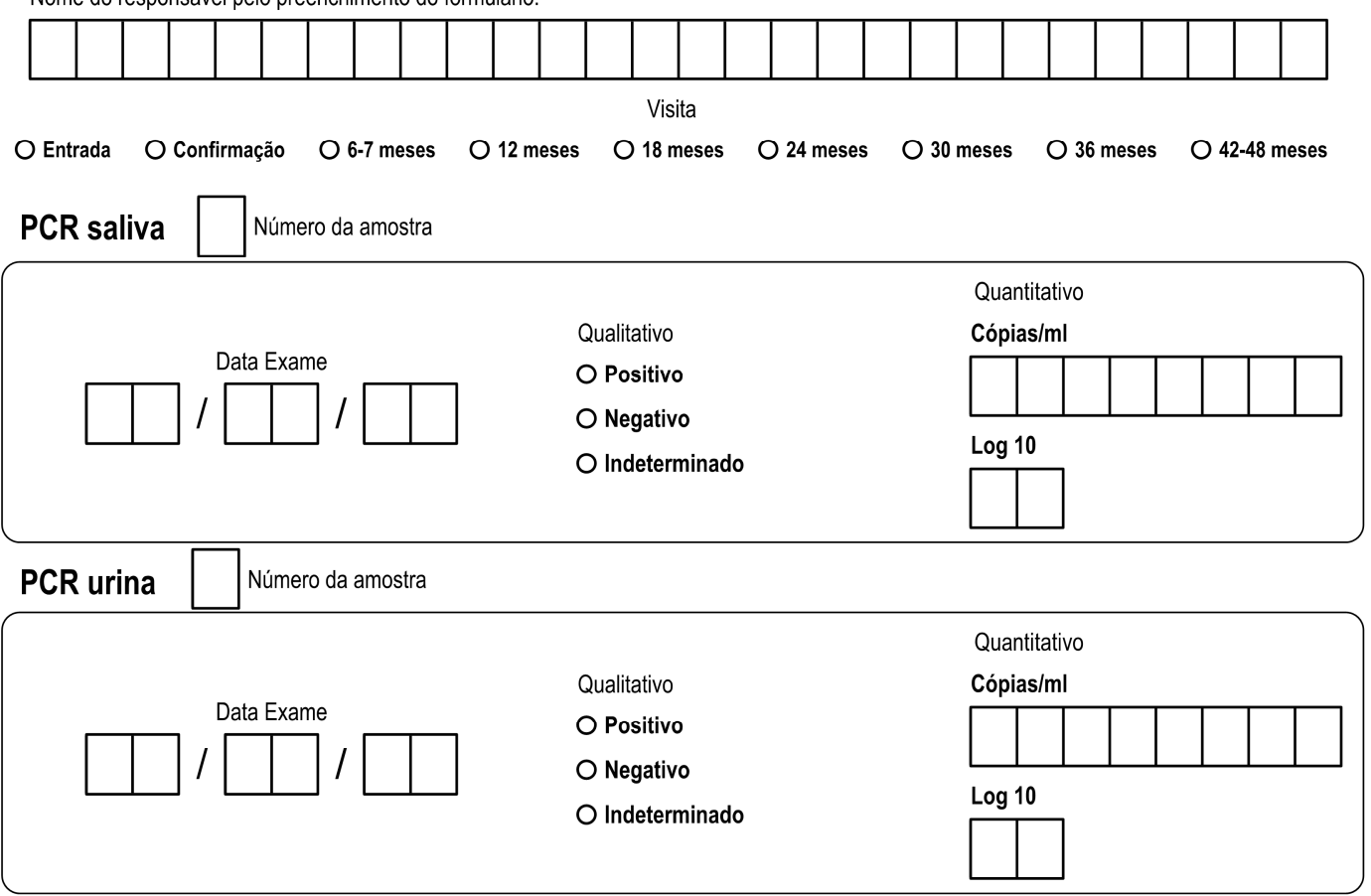

Isolamento viral na saliva $\square$ Número da amostra

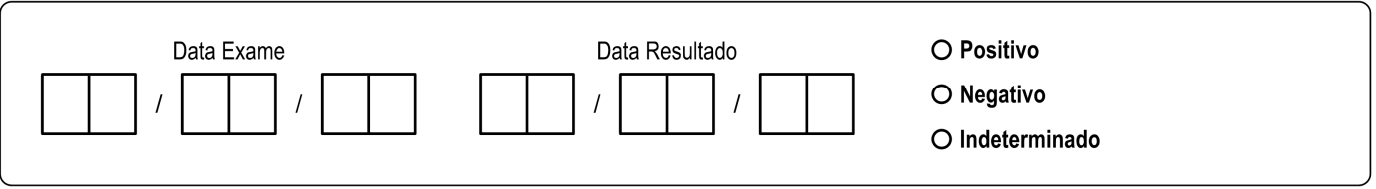

Isolamento viral na urina

Número da amostra

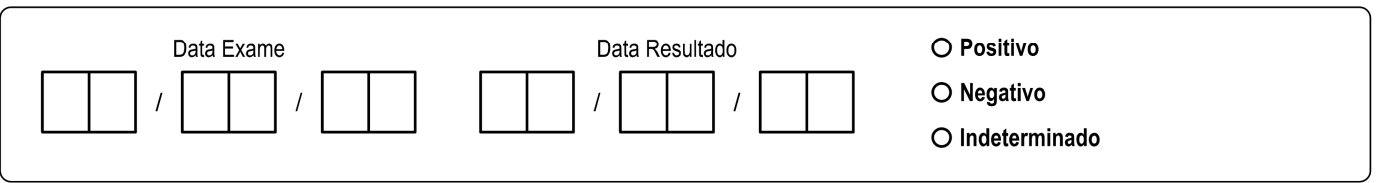


Anexo 3 - Cálculos da sensibilidade e especificidade para cada valor da carga do DNA do CMV e sua associação com a ocorrência de surdez, alterações de NTF e/ou RMc e sinais clínicos sugestivos de infecção congênita por CMV.

\begin{tabular}{|c|c|c|c|c|c|c|c|}
\hline \multirow[b]{2}{*}{ Paciente } & \multirow{2}{*}{$\begin{array}{l}\text { CV } \\
(\log )\end{array}$} & \multicolumn{2}{|l|}{ Surdez } & \multirow[b]{2}{*}{ Paciente } & \multirow{2}{*}{$\begin{array}{l}\text { CV } \\
(\log )\end{array}$} & \multicolumn{2}{|l|}{ Surdez } \\
\hline & & Especificidade & Sensibilidade & & & Especificidade & Sensibilidade \\
\hline 1 & 3,15 & 0,00 & 1,00 & 34 & 6,42 & 0,53 & 0,71 \\
\hline 2 & 3,53 & 0,02 & 1,00 & 35 & 6,42 & 0,54 & 0,71 \\
\hline 3 & 4,14 & 0,03 & 1,00 & 36 & 6,50 & 0,56 & 0,71 \\
\hline 4 & 4,23 & 0,05 & 1,00 & 37 & 6,52 & 0,56 & 0,57 \\
\hline 5 & 4,28 & 0,07 & 1,00 & 38 & 6,53 & 0,58 & 0,57 \\
\hline 6 & 4,39 & 0,08 & 1,00 & 39 & 6,65 & 0,59 & 0,57 \\
\hline 7 & 4,43 & 0,10 & 1,00 & 40 & 6,70 & 0,61 & 0,57 \\
\hline 8 & 4,47 & 0,12 & 1,00 & 41 & 6,72 & 0,63 & 0,57 \\
\hline 9 & 4,73 & 0,14 & 1,00 & 42 & 6,86 & 0,64 & 0,57 \\
\hline 10 & 4,79 & 0,15 & 1,00 & 43 & 6,96 & 0,66 & 0,57 \\
\hline 11 & 5,01 & 0,17 & 1,00 & 44 & 7,00 & 0,68 & 0,57 \\
\hline 12 & 5,10 & 0,19 & 1,00 & 45 & 7,03 & 0,68 & 0,43 \\
\hline 13 & 5,14 & 0,20 & 1,00 & 46 & 7,03 & 0,68 & 0,29 \\
\hline 14 & 5,19 & 0,22 & 1,00 & 47 & 7,05 & 0,69 & 0,29 \\
\hline 15 & 5,21 & 0,24 & 1,00 & 48 & 7,07 & 0,71 & 0,29 \\
\hline 16 & 5,25 & 0,25 & 1,00 & 49 & 7,12 & 0,73 & 0,29 \\
\hline 17 & 5,28 & 0,27 & 1,00 & 50 & 7,12 & 0,75 & 0,29 \\
\hline 18 & 5,29 & 0,29 & 1,00 & 51 & 7,16 & 0,76 & 0,29 \\
\hline 19 & 5,30 & 0,29 & 0,86 & 52 & 7,21 & 0,78 & 0,29 \\
\hline 20 & 5,35 & 0,31 & 0,86 & 53 & 7,51 & 0,80 & 0,29 \\
\hline 21 & 5,36 & 0,32 & 0,86 & 54 & 7,68 & 0,81 & 0,29 \\
\hline 22 & 5,53 & 0,34 & 0,86 & 55 & 7,87 & 0,83 & 0,29 \\
\hline 23 & 5,57 & 0,36 & 0,86 & 56 & 7,87 & 0,83 & 0,29 \\
\hline 24 & 5,58 & 0,37 & 0,86 & 57 & 7,91 & 0,86 & 0,29 \\
\hline 25 & 5,58 & 0,37 & 0,86 & 58 & 8,11 & 0,88 & 0,29 \\
\hline 26 & 5,71 & 0,41 & 0,86 & 59 & 8,18 & 0,90 & 0,29 \\
\hline 27 & 5,75 & 0,42 & 0,86 & 60 & 8,24 & 0,92 & 0,29 \\
\hline 28 & 5,93 & 0,42 & 0,71 & 61 & 8,35 & 0,93 & 0,29 \\
\hline 29 & 5,96 & 0,44 & 0,71 & 62 & 8,35 & 0,95 & 0,29 \\
\hline 30 & 6,14 & 0,46 & 0,71 & 63 & 8,44 & 0,97 & 0,29 \\
\hline 31 & 6,35 & 0,47 & 0,71 & 64 & 8,50 & 0,97 & 0,14 \\
\hline 32 & 6,39 & 0,49 & 0,71 & 65 & 8,80 & 0,98 & 0,14 \\
\hline 33 & 6,40 & 0,51 & 0,71 & 66 & 8,89 & 1,00 & 0,14 \\
\hline
\end{tabular}




\begin{tabular}{|c|c|c|c|c|c|c|c|}
\hline \multirow[b]{2}{*}{ Paciente } & \multirow{2}{*}{$\begin{array}{l}\text { CV } \\
(\log )\end{array}$} & \multicolumn{2}{|c|}{ Alteração de NTF e/ou RMc } & \multirow[b]{2}{*}{ Paciente } & \multirow{2}{*}{$\begin{array}{l}\text { CV } \\
(\log )\end{array}$} & \multicolumn{2}{|c|}{ Alteração de NTF e/ou RMc } \\
\hline & & Especificidade & Sensibilidade & & & Especificidade & Sensibilidade \\
\hline 1 & 3,15 & 0,00 & 1,00 & 34 & 6,42 & 0,50 & 0,57 \\
\hline 2 & 3,53 & 0,00 & 0,97 & 35 & 6,42 & 0,50 & 0,54 \\
\hline 3 & 4,14 & 0,00 & 0,95 & 36 & 6,50 & 0,50 & 0,51 \\
\hline 4 & 4,23 & 0,00 & 0,92 & 37 & 6,52 & 0,50 & 0,49 \\
\hline 5 & 4,28 & 0,00 & 0,89 & 38 & 6,53 & 0,55 & 0,49 \\
\hline 6 & 4,39 & 0,00 & 0,89 & 39 & 6,65 & 0,55 & 0,46 \\
\hline 7 & 4,43 & 0,05 & 0,89 & 40 & 6,70 & 0,55 & 0,43 \\
\hline 8 & 4,47 & 0,05 & 0,89 & 41 & 6,72 & 0,59 & 0,43 \\
\hline 9 & 4,73 & 0,09 & 0,89 & 42 & 6,86 & 0,59 & 0,43 \\
\hline 10 & 4,79 & 0,09 & 0,89 & 43 & 6,96 & 0,64 & 0,43 \\
\hline 11 & 5,01 & 0,14 & 0,89 & 44 & 7,00 & 0,68 & 0,43 \\
\hline 12 & 5,10 & 0,14 & 0,86 & 45 & 7,03 & 0,68 & 0,41 \\
\hline 13 & 5,14 & 0,14 & 0,84 & 46 & 7,03 & 0,68 & 0,38 \\
\hline 14 & 5,19 & 0,14 & 0,81 & 47 & 7,05 & 0,68 & 0,35 \\
\hline 15 & 5,21 & 0,14 & 0,78 & 48 & 7,07 & 0,73 & 0,35 \\
\hline 16 & 5,25 & 0,14 & 0,76 & 49 & 7,12 & 0,77 & 0,35 \\
\hline 17 & 5,28 & 0,14 & 0,73 & 50 & 7,12 & 0,77 & 0,32 \\
\hline 18 & 5,29 & 0,14 & 0,70 & 51 & 7,16 & 0,77 & 0,30 \\
\hline 19 & 5,30 & 0,18 & 0,70 & 52 & 7,21 & 0,77 & 0,27 \\
\hline 20 & 5,35 & 0,18 & 0,70 & 53 & 7,51 & 0,77 & 0,24 \\
\hline 21 & 5,36 & 0,18 & 0,68 & 54 & 7,68 & 0,82 & 0,24 \\
\hline 22 & 5,53 & 0,18 & 0,68 & 55 & 7,87 & 0,86 & 0,24 \\
\hline 23 & 5,57 & 0,23 & 0,68 & 56 & 7,87 & 0,86 & 0,24 \\
\hline 24 & 5,58 & 0,27 & 0,68 & 57 & 7,91 & 0,91 & 0,22 \\
\hline 25 & 5,58 & 0,27 & 0,68 & 58 & 8,11 & 0,91 & 0,19 \\
\hline 26 & 5,71 & 0,27 & 0,65 & 59 & 8,18 & 0,95 & 0,19 \\
\hline 27 & 5,75 & 0,32 & 0,65 & 60 & 8,24 & 0,95 & 0,16 \\
\hline 28 & 5,93 & 0,32 & 0,62 & 61 & 8,35 & 0,95 & 0,14 \\
\hline 29 & 5,96 & 0,32 & 0,59 & 62 & 8,35 & 1,00 & 0,14 \\
\hline 30 & 6,14 & 0,32 & 0,57 & 63 & 8,44 & 1,00 & 0,11 \\
\hline 31 & 6,35 & 0,36 & 0,57 & 64 & 8,50 & 1,00 & 0,08 \\
\hline 32 & 6,39 & 0,41 & 0,57 & 65 & 8,80 & 1,00 & 0,05 \\
\hline 33 & 6,40 & 0,45 & 0,57 & 66 & 8,89 & 1,00 & 0,03 \\
\hline
\end{tabular}




\begin{tabular}{|c|c|c|c|c|c|c|c|}
\hline \multirow[b]{2}{*}{ Paciente } & \multirow{2}{*}{$\begin{array}{l}\text { CV } \\
(\log )\end{array}$} & \multicolumn{2}{|l|}{ Sintomas } & \multirow[b]{2}{*}{ Paciente } & \multirow{2}{*}{$\begin{array}{l}\text { CV } \\
(\log )\end{array}$} & \multicolumn{2}{|l|}{ Sintomas } \\
\hline & & Especificidade & Sensibilidade & & & Especificidade & Sensibilidade \\
\hline 1 & 3,15 & 0,00 & 1,00 & 34 & 6,42 & 0,53 & 0,75 \\
\hline 2 & 3,53 & 0,02 & 1,00 & 35 & 6,42 & 0,55 & 0,75 \\
\hline 3 & 4,14 & 0,03 & 1,00 & 36 & 6,50 & 0,57 & 0,75 \\
\hline 4 & 4,23 & 0,05 & 1,00 & 37 & 6,52 & 0,57 & 0,63 \\
\hline 5 & 4,28 & 0,07 & 1,00 & 38 & 6,53 & 0,59 & 0,63 \\
\hline 6 & 4,39 & 0,09 & 1,00 & 39 & 6,65 & 0,60 & 0,63 \\
\hline 7 & 4,43 & 0,10 & 1,00 & 40 & 6,70 & 0,62 & 0,63 \\
\hline 8 & 4,47 & 0,12 & 1,00 & 41 & 6,72 & 0,64 & 0,63 \\
\hline 9 & 4,73 & 0,14 & 1,00 & 42 & 6,86 & 0,66 & 0,63 \\
\hline 10 & 4,79 & 0,16 & 1,00 & 43 & 6,96 & 0,67 & 0,63 \\
\hline 11 & 5,01 & 0,17 & 1,00 & 44 & 7,00 & 0,69 & 0,63 \\
\hline 12 & 5,10 & 0,19 & 1,00 & 45 & 7,03 & 0,71 & 0,63 \\
\hline 13 & 5,14 & 0,21 & 1,00 & 46 & 7,03 & 0,72 & 0,63 \\
\hline 14 & 5,19 & 0,22 & 1,00 & 47 & 7,05 & 0,74 & 0,63 \\
\hline 15 & 5,21 & 0,24 & 1,00 & 48 & 7,07 & 0,76 & 0,63 \\
\hline 16 & 5,25 & 0,26 & 1,00 & 49 & 7,12 & 0,78 & 0,63 \\
\hline 17 & 5,28 & 0,28 & 1,00 & 50 & 7,12 & 0,79 & 0,63 \\
\hline 18 & 5,29 & 0,29 & 1,00 & 51 & 7,16 & 0,81 & 0,63 \\
\hline 19 & 5,30 & 0,31 & 1,00 & 52 & 7,21 & 0,83 & 0,63 \\
\hline 20 & 5,35 & 0,33 & 1,00 & 53 & 7,51 & 0,84 & 0,63 \\
\hline 21 & 5,36 & 0,33 & 0,88 & 54 & 7,68 & 0,86 & 0,63 \\
\hline 22 & 5,53 & 0,34 & 0,88 & 55 & 7,87 & 0,88 & 0,63 \\
\hline 23 & 5,57 & 0,36 & 0,88 & 56 & 7,87 & 0,88 & 0,63 \\
\hline 24 & 5,58 & 0,38 & 0,88 & 57 & 7,91 & 0,91 & 0,63 \\
\hline 25 & 5,58 & 0,38 & 0,88 & 58 & 8,11 & 0,93 & 0,63 \\
\hline 26 & 5,71 & 0,40 & 0,75 & 59 & 8,18 & 0,95 & 0,63 \\
\hline 27 & 5,75 & 0,41 & 0,75 & 60 & 8,24 & 0,97 & 0,63 \\
\hline 28 & 5,93 & 0,43 & 0,75 & 61 & 8,35 & 0,97 & 0,50 \\
\hline 29 & 5,96 & 0,45 & 0,75 & 62 & 8,35 & 0,98 & 0,50 \\
\hline 30 & 6,14 & 0,47 & 0,75 & 63 & 8,44 & 0,98 & 0,38 \\
\hline 31 & 6,35 & 0,48 & 0,75 & 64 & 8,50 & 0,98 & 0,25 \\
\hline 32 & 6,39 & 0,50 & 0,75 & 65 & 8,80 & 1,00 & 0,25 \\
\hline 33 & 6,40 & 0,52 & 0,75 & 66 & 8,89 & 1,00 & 0,13 \\
\hline
\end{tabular}


Anexo 4 - Achados de NTF em 29 crianças e respectivos achados de TC e/ou RMc.

\begin{tabular}{|c|c|c|}
\hline NIP & Neurossonografia Transfontanelar (NTF) & TC OU RMc \\
\hline 110047 & calcificação parenquimatosa & calcificação parenquimatosa \\
\hline 1100851 & vasculopatia lenticuloestriada & Normal \\
\hline 2200026 & cisto subependimário & não realizado \\
\hline 1101116 & cistos subependimários & Normal \\
\hline 2200749 & $\begin{array}{c}\text { cistos subependimários e calcificações } \\
\text { periventriculares }\end{array}$ & $\begin{array}{c}\text { áreas de hipersinal na região peritrigonal bilateral, que } \\
\text { podem corresponder a regiões de mielinização } \\
\text { terminal. }\end{array}$ \\
\hline 2201159 & calcificação talâmica & não realizado \\
\hline 2202087 & cistos subependimários & calcificação puntiforme e cisto subependimário \\
\hline 2202514 & $\begin{array}{l}\text { cistos subependimários,ventriculomegalia, } \\
\text { calcificações periventriculares }\end{array}$ & $\begin{array}{l}\text { cistos subependimários, discreta ventriculomegalia } \\
\text { supratentorial }\end{array}$ \\
\hline 9910030 & cistos subependimários & não realizado \\
\hline 2202614 & cistos subependimários & gliose e desmielinização occipital bilateral \\
\hline 2202649 & vasculopatia lenticuloestriada & não realizado \\
\hline 2202748 & $\begin{array}{c}\text { cistos subependimários, calcificações } \\
\text { periventriculares e vasculopatia lenticuloestriada }\end{array}$ & não realizado \\
\hline 99400053 & vasculopatia lenticuloestriada & $\begin{array}{c}\text { alteração de substância branca peritrigonal compatível } \\
\text { com mielinização terminal }\end{array}$ \\
\hline 2203102 & cisto na região pineal & não realizado \\
\hline 2203429 & cisto subependimário, vasculopatia talamoestriatal & $\begin{array}{c}\text { alteração de sinal em regiões peritrigonais sugerindo } \\
\text { gliose ou alteração da mielina }\end{array}$ \\
\hline 1100614 & $\begin{array}{l}\text { hemorragia de plexo coroide, ventriculomegalia, } \\
\text { lesão neuronal seletiva focal }\end{array}$ & $\begin{array}{l}\text { redução volumétrica cerebral com padrão de } \\
\text { leucomalácia periventricular, atrofia de hipocampos, } \\
\text { comprometimento luz do aqueduto mesencefálico }\end{array}$ \\
\hline 1103838 & cisto de plexo coroide & não realizado \\
\hline 2204088 & cisto subependimário & não realizado \\
\hline 1103102 & $\begin{array}{l}\text { hemorragia intraventricular, vasculopatia } \\
\text { lenticuloestriada }\end{array}$ & $\begin{array}{l}\text { hipomielinização parietal periventricular podendo } \\
\text { corresponder a mielinização terminal ou lesão por } \\
\text { leucomalácia }\end{array}$ \\
\hline 2204170 & $\begin{array}{l}\text { vasculopatia lenticuloestriada, cistos de plexo } \\
\text { coroide }\end{array}$ & $\begin{array}{l}\text { alteração de sinal de substância branca profunda, } \\
\text { podendo representar áreas de mielinização terminal } \\
\text { sem outras alterações }\end{array}$ \\
\hline 1103107 & $\begin{array}{c}\text { cistos subependimários e calcificações } \\
\text { parenquimatosas e periventriculares }\end{array}$ & Normal \\
\hline 1103207 & $\begin{array}{c}\text { calcificações parenquimatosas, ventriculomegalia, } \\
\text { cistos subependimários, vasculopatia } \\
\text { lenticuloestriada. }\end{array}$ & $\begin{array}{l}\text { discreta alteração de sinal de substância branca } \\
\text { periventricular associada a pequenos cistos }\end{array}$ \\
\hline 2204354 & cisto subependimário & não realizado \\
\hline 2205129 & $\begin{array}{l}\text { vasculopatia lenticuloestriada, cisto de plexo } \\
\text { coroide }\end{array}$ & não realizado \\
\hline 1103888 & $\begin{array}{l}\text { vasculopatia lenticuloestriada, cistos } \\
\text { subependimários e de plexo coroide }\end{array}$ & não realizado \\
\hline 1103922 & cistos agrupados subependimários a esquerda & não realizado \\
\hline 1103995 & pequeno cisto subependimário & não realizado \\
\hline 99200373 & cistos subependimários & não realizado \\
\hline 99200359 & $\begin{array}{l}\text { vasculopatia lenticuloestriada bilateralmente; } \\
\text { provável calcificação amorfa em tálamo direito, } \\
\text { cistos subependimários bilateralmente }\end{array}$ & não realizado \\
\hline
\end{tabular}


Anexo 5 - Achados de neuroimagens e exames laboratoriais, respectivas cargas virais, presença ou ausência de restrição do crescimento intrauterino e ocorrência de surdez em 66 crianças com infecção congênita por CMV.

\begin{tabular}{|c|c|c|c|c|c|c|c|}
\hline Paciente & Carga viral urina & NTF & TC/RMc & $\overline{\mathrm{RCIU}}$ & Gama GT & Plaquetas & Surdez \\
\hline 1 & $5,10 \mathrm{E}+05$ & 0 & 2 & 0 & 2 & 0 & 0 \\
\hline 2 & $1,17 \mathrm{E}+07$ & 0 & 0 & 0 & 0 & 0 & 0 \\
\hline 3 & $3,72 \mathrm{E}+05$ & 0 & 2 & 0 & 0 & 0 & 0 \\
\hline 4 & $1,54 \mathrm{E}+05$ & 1 & 1 & 0 & 0 & 0 & 0 \\
\hline 5 & $5,04 \mathrm{E}+06$ & 0 & 2 & 0 & 0 & 0 & 0 \\
\hline 6 & $3,84 \mathrm{E}+05$ & 1 & 2 & 0 & 1 & 1 & 0 \\
\hline 7 & $6,29 \mathrm{E}+08$ & 1 & 1 & 1 & 1 & 1 & 0 \\
\hline 8 & $1,94 \mathrm{E}+05$ & 0 & 0 & 1 & 0 & 0 & 1 \\
\hline 9 & $1,33 \mathrm{E}+07$ & 1 & 0 & 0 & 0 & 0 & 0 \\
\hline 10 & $1,40 \mathrm{E}+03$ & 1 & 2 & 0 & 0 & 0 & 0 \\
\hline 11 & $1,90 \mathrm{E}+04$ & 2 & 2 & 0 & 0 & 0 & 0 \\
\hline 12 & $2,28 \mathrm{E}+05$ & 2 & 2 & 0 & 0 & 0 & 0 \\
\hline 13 & $1,37 \mathrm{E}+05$ & 1 & 0 & 0 & 0 & 0 & 0 \\
\hline 14 & $3,35 \mathrm{E}+03$ & 1 & 1 & 0 & 0 & 0 & 0 \\
\hline 15 & $4,80 \mathrm{E}+07$ & 0 & 2 & 0 & 0 & 0 & 0 \\
\hline 16 & $2,48 \mathrm{E}+06$ & 0 & 2 & 0 & 0 & 0 & 0 \\
\hline 17 & $7,17 \mathrm{E}+06$ & 0 & 2 & 0 & 0 & 0 & 0 \\
\hline 18 & $8,59 \mathrm{E}+05$ & 1 & 2 & 1 & 0 & 0 & 0 \\
\hline 19 & $2,23 \mathrm{E}+06$ & 0 & 2 & 0 & 0 & 0 & 0 \\
\hline 20 & $2,25 \mathrm{E}+08$ & 0 & 2 & 0 & 0 & 0 & 0 \\
\hline 21 & $2,24 \mathrm{E}+05$ & 1 & 1 & 1 & 1 & 1 & 0 \\
\hline 22 & $3,30 \mathrm{E}+06$ & 0 & 2 & 0 & 0 & 0 & 0 \\
\hline 23 & $9,22 \mathrm{E}+06$ & 0 & 2 & 0 & 0 & 0 & 0 \\
\hline 24 & $2,94 \mathrm{E}+04$ & 0 & 2 & 0 & 0 & 0 & 0 \\
\hline 25 & $3,19 \mathrm{E}+06$ & 1 & 1 & 0 & 1 & 1 & 1 \\
\hline 26 & $1,38 \mathrm{E}+04$ & 1 & 1 & 0 & 1 & 0 & 0 \\
\hline 27 & $2,46 \mathrm{E}+04$ & 0 & 2 & 0 & 1 & 0 & 0 \\
\hline 28 & $9,99 \mathrm{E}+06$ & 1 & 1 & 0 & 1 & 0 & 1 \\
\hline 29 & $7,45 \mathrm{E}+07$ & 1 & 2 & 0 & 1 & 0 & 0 \\
\hline 30 & $5,63 \mathrm{E}+05$ & 1 & 1 & 0 & 1 & 0 & 1 \\
\hline 31 & $7,45 \mathrm{E}+07$ & 0 & 2 & 0 & 0 & 0 & 0 \\
\hline 32 & $1,03 \mathrm{E}+05$ & 1 & 2 & 0 & 0 & 0 & 0 \\
\hline 33 & $1,52 \mathrm{E}+08$ & 1 & 2 & 1 & 0 & 0 & 0 \\
\hline 34 & $1,29 \mathrm{E}+08$ & 0 & 0 & 1 & 1 & 0 & 0 \\
\hline 35 & $2,52 \mathrm{E}+06$ & 0 & 2 & 1 & 0 & 0 & 0 \\
\hline
\end{tabular}




\begin{tabular}{|c|c|c|c|c|c|c|c|}
\hline 36 & $4,50 \mathrm{E}+06$ & 1 & 1 & 1 & 1 & 0 & 0 \\
\hline 37 & $6,23 \mathrm{E}+04$ & 0 & 2 & 0 & 0 & 0 & 0 \\
\hline 38 & $1,61 \mathrm{E}+05$ & 1 & 2 & 0 & 0 & 0 & 0 \\
\hline 39 & $3,84 \mathrm{E}+05$ & 2 & 2 & 0 & 2 & 2 & 0 \\
\hline 40 & $1,08 \mathrm{E}+07$ & 1 & 1 & 0 & 1 & 1 & 0 \\
\hline 41 & $9,10 \mathrm{E}+05$ & 1 & 1 & 0 & 0 & 0 & 0 \\
\hline 42 & $1,99 \mathrm{E}+05$ & 2 & 2 & 0 & 1 & 0 & 0 \\
\hline 43 & $1,69 \mathrm{E}+04$ & 1 & 1 & 0 & 1 & 1 & 0 \\
\hline 44 & $1,37 \mathrm{E}+06$ & 0 & 2 & 1 & 0 & 0 & 0 \\
\hline 45 & $1,11 \mathrm{E}+07$ & 0 & 2 & 1 & 0 & 0 & 0 \\
\hline 46 & $2,70 \mathrm{E}+04$ & 2 & 2 & 0 & 0 & 0 & 0 \\
\hline 47 & $1,27 \mathrm{E}+05$ & 1 & 2 & 1 & 0 & 0 & 0 \\
\hline 48 & $2,65 \mathrm{E}+06$ & 1 & 2 & 1 & 1 & 0 & 0 \\
\hline 49 & $3,40 \mathrm{E}+06$ & 1 & 1 & 0 & 0 & 0 & 0 \\
\hline 50 & $2,63 \mathrm{E}+06$ & 1 & 1 & 0 & 0 & 0 & 0 \\
\hline 51 & $3,22 \mathrm{E}+07$ & 0 & 2 & 1 & 0 & 0 & 0 \\
\hline 52 & $1,61 \mathrm{E}+07$ & 1 & 2 & 1 & 1 & 0 & 0 \\
\hline 53 & $3,18 \mathrm{E}+08$ & 1 & 1 & 0 & 0 & 0 & 0 \\
\hline 54 & $1,06 \mathrm{E}+07$ & 1 & 2 & 0 & 0 & 0 & 1 \\
\hline 55 & $2,78 \mathrm{E}+08$ & 1 & 1 & 1 & 1 & 1 & 1 \\
\hline 56 & $5,39 \mathrm{E}+04$ & 2 & 2 & 0 & 1 & 0 & 0 \\
\hline 57 & $1,92 \mathrm{E}+05$ & 1 & 2 & 0 & 0 & 0 & 0 \\
\hline 58 & $7,77 \mathrm{E}+08$ & 1 & 1 & 0 & 1 & 1 & 1 \\
\hline 59 & $3,35 \mathrm{E}+05$ & 0 & 2 & 0 & 0 & 0 & 0 \\
\hline 60 & $1,32 \mathrm{E}+07$ & 1 & 2 & 1 & 0 & 0 & 0 \\
\hline 61 & $1,77 \mathrm{E}+05$ & 1 & 2 & 1 & 0 & 0 & 0 \\
\hline 62 & $1,74 \mathrm{E}+08$ & 1 & 1 & 1 & 1 & 1 & 0 \\
\hline 63 & $2,26 \mathrm{E}+08$ & 1 & 1 & 1 & 1 & 1 & 0 \\
\hline 64 & $1,46 \mathrm{E}+07$ & 1 & 2 & 1 & 1 & 0 & 0 \\
\hline 65 & $8,17 \mathrm{E}+07$ & 1 & 2 & 1 & 0 & 0 & 0 \\
\hline 66 & $5,29 \mathrm{E}+06$ & 1 & 2 & 0 & 0 & 0 & 0 \\
\hline
\end{tabular}

